\title{
Related and unrelated industry variety and the internationalization of start- ups
}

\author{
Lucia Naldi $^{\mathrm{a}, *}$, Giuseppe Criaco ${ }^{\mathrm{b}}$, Pankaj C. Patel ${ }^{\mathrm{c}}$ \\ a Jönköping International Business School, Centre for Entrepreneurship and Spatial Economics (CEnSE), Center for Family Entrepreneurship and Ownership - CeFEO, PO \\ Box 1026, SE-551 11 Jönköping, Sweden \\ ${ }^{\mathrm{b}}$ Erasmus University Rotterdam, RSM - Rotterdam School of Management, Department of Strategic Management and Entrepreneurship, Postbus 1738 , 3000 DR \\ Rotterdam, Netherlands \\ ${ }^{\mathrm{c}}$ Villanova University, Villanova School of Business, 800 Lancaster Ave., Lancaster, PA 19085
}

\section{A R T I C L E I N F O}

\section{Keywords:}

Start-ups

Internationalization

Industry variety

Technological knowledge

Innovation

Export Persistence

\begin{abstract}
A B S T R A C T
We study the relationship between industry variety in a start-up's home location and the start-up's internationalization in terms of both the likelihood of and persistence in exporting. Using a unique sample of Swedish start-ups, we find that related industry variety is positively associated with exporting likelihood and persistence, whereas unrelated industry variety is positively associated with exporting likelihood and persistence when the start-ups' employees possess technological knowledge. We also find that employees' international experience strengthens the positive relationship between related industry variety and start-ups' export persistence. We provide auxiliary evidence of the proposed mechanisms through which related and unrelated industry variety affects start-ups' internationalization-that is, through their effects on start-ups' ability to launch novel products in foreign markets. The findings of our study provide policymakers preliminary evidence on the value of developing and sustaining local knowledge conditions and promoting labor recruitment policies in the home country to promote start-up internationalization.
\end{abstract}

\section{Introduction}

An important indicator of a start-up's growth orientation is its ability to enter and succeed in international markets (Stucki, 2016). Thus, the internationalization of start-ups has received increasing research and policy attention. In the entrepreneurship literature, there is a growing interest in understanding the role of knowledge sourcing from the home location in driving the internationalization of start-ups (Zander et al., 2015). Due to their limited operational history, start-ups may rely on locally sourced knowledge and resources to "leapfrog" internationalization efforts (Bruneel et al., 2010; De Clercq et al., 2012; Yu et al., 2011). In explaining start-up internationalization activities based on local knowledge, Fernhaber et al. (2008) and others (e.g., Lamin and Livanis, 2013; Libaers and Meyer, 2011; Lööf and Nabavi, 2014) have focused on local spillovers of knowledge and resources triggered by the spatial concentration of firms in the same industry and industrial clustering.

However, the role of other types of knowledge spillovers in the internationalization of start-ups remains largely understudied in the literature. For instance, we know little about the role of spillovers of knowledge that span multiple technological areas and are triggered by spatially proximate firms in a variety of industries. These spillovers, known as Jacobian externalities (Jacobs, 1970), could prime or impel start-ups' internationalization. On the one hand, the local industry variety in a start-up location can be an important driver of internationalization because exposure to knowledge and capabilities in multiple and diverse fields can enable start-ups to recombine novel resources and create new products (Chandra et al., 2012; Eckhardt and Shane, 2003; Mainela et al., 2014) to spur internationalization (Autio, 2005; Olausson and Berggren, 2010). As noted by Cassiman and Golovko (2011) "[p]rior research found innovation, and more specifically product innovation, to be an important factor in explaining the entry into the export market". On the other hand, the potential value of knowledge spillovers from local industry variety also poses some challenges to start-up internationalization. Assimilating and recombining knowledge from multiple and unrelated technological areas is costly (Cohen and Levinthal, 1990; Penrose, 1959), and the product development outcomes of such recombination are uncertain (Katila and Ahuja, 2002)—which might affect a start-up's ability to enter and successfully compete in international markets (Beise-Zee and

\footnotetext{
* Corresponding author.

E-mail addresses: lucia.naldi@ju.se (L. Naldi), criaco@rsm.nl (G. Criaco), pankaj.patel@villanova.edu (P.C. Patel).
} 
Rammer, 2006; Kotha et al., 2011; Malerba, 2002).

In this study, we draw on the literature on Jacobian externalities to ask whether local industry variety impacts the internationalization of start-ups. To answer this question, we utilize Frenken et al.'s (2007) distinction between related and unrelated industry variety. Related industry variety represents the variety (or spread) of co-located firms within industries that share knowledge complementarities among products, whereas unrelated industry variety represents the variety (or spread) of co-located firms between industries that do not share knowledge complementarities among products. We predict that both types of variety can favor the internationalization of start-ups(Acs and Terjesen, 2013)(Acs and Terjesen, 2013). However, assimilating and recombining knowledge from multiple unrelated industries may be more uncertain and costly than assimilating and recombining knowledge from multiple related industries. Therefore, we expect that compared to unrelated industry variety, related industry variety in a startup's location has a stronger positive relationship with internationalization.

Furthermore, the relationship between related or unrelated variety and the internationalization of a start-up could be contingent on the start-up's available "horsepower" to absorb and leverage the variety of local knowledge. In accordance with the literature on absorptive capacity (Cohen and Levinthal, 1989, 1990; Crescenzi and Gagliardi, 2018; Lane and Lubatkin, 1998; Lane et al., 2001), we further investigate whether the technological knowledge and international experience of a start-up's human resources (all employees, including the founder) moderate the relationship between related or unrelated industry variety and internationalization (Cohen and Levinthal, 1990; Ganotakis and Love, 2012).

We test our model using a unique sample of 3686 Swedish start-ups founded in 2002, 2003, 2004, or 2005 and followed until 2010. Following prior research, we conceptualize the internationalization of start-ups in terms of export behavior and define it in a dual way: a) as the probability that a start-up exports (Basile, 2001) and b) as the startup's export persistence (Love and Máñez, 2019; Sui and Baum, 2014). While these two dimensions are theoretically closely related-that is, we expect that the theoretical arguments we develop in our study apply to both in similar ways-the inclusion of the latter dimension is important for assessing business and policy implications because the duration (or persistence) of a start-up's exports captures the mid- to long-term success of its internationalization efforts (Alvarez, 2007).

To the extent possible, we empirically corroborate our underlying theoretical reasoning with additional auxiliary analyses. Specifically, we provide evidence that related industry variety in a start-up's location is positively associated with the start-up's number of product innovations and that unrelated industry variety is positively associated with breakthrough product innovation. Both product innovation and breakthrough product innovation, in turn, are positively associated with the exporting persistence of start-ups.

This study makes three main contributions. First, it extends the prior research in the international entrepreneurship literature on the role of home location in the internationalization of start-ups (Fernhaber et al., 2008; Lamin and Livanis, 2013; Libaers and Meyer, 2011; Lööf and Nabavi, 2014; Murmann et al., 2015) by utilizing the longstanding economic geography literature on Jacobian externalities. Second, it contributes to both the international entrepreneurship and economic geography literature by explaining the conditions under which start-ups can better benefit from related and unrelated industry variety to enter and persist in international markets. By focusing on the technological knowledge and international experience of all members (founders and employees), rather than just those of members of the upper echelons, we also respond to the call for empirical research to consider the "people" factor in the internationalization of start-ups (Knight and Liesch, 2002). Finally, by studying the determinants of a start-up's export persistence, we redirect attention to an important yet under-researched dimension of a start-up's international behavior, which has important implications for its mid- to long-term growth (Alvarez, 2007).

\section{Background literature}

\subsection{Knowledge and start-up internationalization}

The international entrepreneurship literature has recognized the importance of knowledge sourced outside the venture as a key enabler of a start-up's ability to internationalize after inception (Fernhaber et al., 2009; Knight and Cavusgil, 2004; Yu et al., 2011) and thus to leapfrog the incremental internationalization processes prescribed in internationalization theories (Bruneel et al., 2010; De Clercq et al., 2012). Prior research has identified two types of knowledge known to facilitate the internationalization of start-ups: foreign market knowledge and technological knowledge (Denicolai et al., 2014; Fletcher and Harris, 2012). Foreign market knowledge incorporates “information about host countries' financial, cultural, social, and political conditions as well as general facts about country differences and how international business operations are conducted" (Yu et al., 2011: 426). While foreign market knowledge is mainly obtained through direct experience in foreign markets, technological knowledge can—at least partially-be externally sourced. A number of studies have explained the internationalization of start-ups and their expansion in international markets by their ability to leverage technological knowledge and develop innovative products and solutions (Autio et al., 2000; Knight and Cavusgil, 2004; Zahra et al., 2000). Vernon (1966) seminal work hypothesized that innovation-especially product innovation -is the main driver of a firm's internationalization, following its product life-cycle. More recently, research has shown that start-ups that develop innovative products start exporting "to exploit their market power in foreign markets because of the limits the domestic market poses in the early growth stage" (Cassiman and Golovko, 2011: 58) or are pushed to internationalize to benefit from first- and second-mover advantages (Chetty and Campbell-Hunt, 2004) to prevent competitors from reaping these innovations (Madsen and Servais, 1997).

Research also suggests that developing novel products for entering and succeeding in international markets requires a broad spectrum of technological knowledge. Specifically, what matters is not only the amount of technological knowledge but also the breadth or heterogeneity of this knowledge. For example, Zahra et al. (2000) show that the breadth of technological learning is a key driver of internationalization in start-ups. Additionally, Nassimbeni (2001) finds that a small firm's ability to break into a foreign market and successfully compete against local offers is closely related to the range of technologies held by the firm.

A question that continues to intrigue scholars is where start-ups-with limited operational history-can find the varied and diverse technological knowledge that favors their internationalization based on innovation (Zander et al., 2015). In this paper, we argue that co-located firms in a variety of industries can provide start-ups with the type of knowledge and externalities that favor recombinant innovation and foster their internationalization. ${ }^{1}$ Bell and Zaheer (2007) propose that

\footnotetext{
${ }^{1}$ It is important to acknowledge that the economics and international business (IB) literature has provided different yet complementary perspectives to understand why firms start to export. As summarized by Bernini et al. (2016: 1060) " $[w]$ hile the economics literature has tended to regard firm-level productivity to be the 'catch-all' determinant of heterogeneous export behavior, the IB literature in parallel has adopted a more complex and nuanced view, and explored these questions in the framework of the resource-based view and firmspecific advantages". Specifically, in the IB tradition, including the international entrepreneurship literature, the focus has been more on identifying the unique bundles of resources and knowledge that make firms more productive-including more innovative, especially in the case of start-ups - to enter and
} 
physical proximity favors the transmission of knowledge through impromptu exchanges outside the organization and that proximity favors the development of trust; this, in turn, fosters communication and knowledge flow among individuals and firms. In accordance with existing research in economic geography, we characterize local knowledge as the pool of knowledge transferred, both intentionally and unintentionally, from co-located actors (Iammarino and McCann, 2013). Building on the work of Jacobs (1970), we argue that the variety of colocated firms may be an important source of knowledge spillovers and local learning that increases start-ups' creativity and innovations based on the recombination of knowledge from multiple technological areas. Local industry variety refers to the extent to which a location hosts firms from multiple industries whose knowledge spillovers spread across different technological domains; thus, it captures the degree of heterogeneity (or the breadth) of the knowledge content in a certain location (Bernini et al., 2016; Colombelli and Quatraro, 2018; Frenken et al., 2007; Jacobs, 1970; McCann and Folta, 2008; McCann and Simonen, 2005).

\subsection{Industry variety}

The relevance of industry variety is discussed in strategic management and economic theories as well as in economic geography and regional studies. The prominent benefits of industry variety relate to learning and innovation. The organizational learning literature has supported the role of variation (Schilling et al., 2003) and the exposure to knowledge and resource heterogeneity (Gilsing et al., 2008). It is argued that firms may benefit from exposure to multiple ideas and experiences; this exposure allows them to think creatively and develop novel combinations of knowledge (Levinthal and March 1993; Levitt and March 1988). Conversely, "the lack of variety means... that there will be less opportunity for firms to learn-that is, to directly or indirectly benefit from the diverse experiences of other firms" (Miles et al., 1993: 1975). The innovation literature has also proposed that important innovations are more often the result of borrowing and recombining knowledge from disparate fields than the result of an intensive focus on a single field (Schilling et al., 2003).

Economic geography research has studied the effects of local industry variety mostly on growth and innovation outcomes. The attention has largely been placed on outcomes at the regional level. Paci and Usai (1999), for example, show that the diversity of externalities positively affects regional innovativeness, measured in terms of patents. In more recent work, Frenken et al. (2007) argue that local variety is not a unidimensional construct but a two-dimensional construct consisting of related (within-sector) and unrelated (across-sector) variety. Specifically, they hold that recombinant innovation is primarily a function of related variety because it entails recombining ideas across multiple technological areas that are technically closer and not completely disconnected, as in the case of unrelated industry variety. After Frenken and colleagues' work, several studies have examined the differential effects of related and unrelated industry variety on regional outcomes, including innovation. For instance, Tavassoli and Carbonara (2014) find that the innovation of regions increases with industry variety. Without denying the key role of related variety in innovation, Castaldi et al. (2015: 770) recognize that incoming knowledge of unrelated variety may also sometimes be combined successfully and give rise to innovations that, when successful, might be more breakthrough in nature given that "recombination across unrelated technologies can

\section{(footnote continued)}

succeed in international markets. We agree with Bernini et al. (2016) that the economics and IB perspectives are complementary. In the specific case of our research, co-located firms in a variety of industries might provide start-ups with the bundles of knowledge and resources that make them more innovative and productive for entering and competing in export markets. lead to complete new operational principles, functionalities and applications". Thus, using patent data, Castaldi and colleagues (2015) predict and find evidence that related technological variety is associated with innovation in general (in line with Tavassoli and Carbonara 2014) and that unrelated technological variety is associated with breakthrough innovation. Borrowing from Castaldi et al. (2015) use of technological classifications of patents to construct the measures related and unrelated variety and accounting for the role of non-location knowledge sources, Miguelez and Moreno (2018) find that related technological variety is conducive to regional innovation and that unrelated technological variety plays a vital role in radical innovation. In the Italian context, Colombelli (2016) finds that both related and unrelated variety are associated with the formation of innovative new firms, and Antonietti and Gambarotto (2018) find that new start-ups are more frequently located in places where local levels of both related and unrelated variety are high, but where related variety has a stronger positive effect than unrelated variety. They also find that innovative start-ups are more frequent in locations where unrelated variety is higher.

Only a limited number of studies have examined the effects of industry variety on firm-level outcomes. In a sample of Italian firms, Antonietti and Cainelli (2011) do not find significant and consistent effects of related or unrelated variety on firm innovation or exporting in a sample of Italian firms. Merging data from the community innovation survey (CIS) with data from Statistics Norway, Aarstad et al. (2016) find that related variety has a positive effect on a firm's propensity to launch new products, while unrelated industry variety has a negative effect on firm productivity. In another study on Norwegian firms, Aarstad et al. (2019) find that unrelated industry variety increases a firm's propensity for and amount of R\&D. Employing geo-coded firmlevel panel data from Sweden, Andersson et al. (2019) find that firms can benefit—in terms of productivity-from unrelated industry variety and that externalities from knowledge diversity are likely to operate at both the neighborhood and city levels.

Overall, most studies find support for the positive effect of related variety on recombinant innovation. While this finding supports our general argument that being located around firms in a variety of industries can provide start-ups with the varied technological knowledge needed to develop novel products for international markets, the relationship between related industry variety in a start-up's location and the start-up's internationalization has not been explicitly examined.

Current studies also provide some evidence of the benefits of unrelated industry variety, especially in terms of inducing radical or breakthrough innovations due to the opportunity to recombine knowledge from varied and diverse technological areas. However, they also cast some doubts about the actual possibility of recombining knowledge from very different technological areas. Thus, in relation to our interest in start-ups' sourcing and recombining varied knowledge from other co-located firms in a variety of different industries to internationalize, these studies raise some concerns regarding the extent to which and the conditions under which start-ups may absorb knowledge from other co-located firms in unrelated industries and use this knowledge to internationalize.

\subsection{Absorptive capacity of externally sourced knowledge}

The challenges associated with absorbing and using knowledge from a variety of different sources have been widely discussed in the innovation and absorptive capacity literature. Prior studies suggest that spillovers from a variety of sources can create knowledge reliability problems (Denrell, 2003) because of the increased complexity in the identification of cause-effect linkages (Zollo, 2009). A basic premise of the absorptive capacity construct is that firms must manage the heterogeneity of external knowledge (Cohen and Levinthal, 1990; Zahra and George, 2002). While recombining heterogeneous knowledge from external sources may be valuable, start-ups encounter 
difficulties and additional costs, particularly when they cannot close the cognitive distance with such knowledge (Nooteboom, 2000). The difficulties may manifest in differences in fundamental factors, such as differences in practices and approaches to problem-solving, and more prosaic issues, such as differences in technical terms (Phene et al., 2006). The additional costs instead typically originate from the need to devote human resources to absorbing and recombining unrelated knowledge. Cohen and Levinthal (1990: 150) explain that when "a firm wishes to acquire and use knowledge which is unrelated to its ongoing activity", it needs "personnel with the requisite breadth of knowledge that would permit absorption of knowledge from new domains". On the other hand, the acquisition and recombination of related knowledge "is more of a byproduct of routine activities" (Cohen and Levinthal, 1990: 129). Thus, the acquisition and recombination of related knowledge are less costly in terms of time and effort.

The critical considerations above guided our choice of the characteristics of local industry variety to gain a better understanding of its direct effect on start-up internationalization; accordingly, we focus on related and unrelated variety as key dimensions. We define related industry variety in the home location of a start-up as the variety within the industries related to that of the start-up. Conversely, unrelated industry variety in the home location of a start-up is the variety between unrelated industries (Frenken et al., 2007). Furthermore, given the role of a start-up's human resources in absorbing and using knowledge from external sources, we focus on two dimensions as moderators: technological knowledge and international experience of the start-up's employees.

\section{Hypothesis development}

The overarching logic of our conceptual model is summarized in Fig. 1. It schematically indicates that we expect both related and unrelated industry variety to be positively associated with start-ups' internationalization in terms of both their likelihood of and persistence in exporting (as specified in Hypothesis 1 and Hypothesis 2, respectively). We also propose that the relationship between industry variety and internationalization is stronger for related industry variety than for unrelated industry variety (Hypothesis 3). Furthermore, we predict that the relationship between unrelated/related industry variety and a startup's internationalization will be stronger when the employees of the start-up have technological knowledge (Hypothesis 4 and Hypothesis 5) or international experience (Hypothesis 6 and Hypothesis 7).

\subsection{Related industry variety and start-up internationalization}

Prior research has shown that related variety in a firm's location favors the novel recombination of knowledge that leads to innovations, such as new products based on improved technologies as well as novel products (Castaldi et al., 2015). These innovations are important for firms to enter and successfully compete in international markets
(Yeoh, 2004). A substantial body of empirical research shows that novel products are important for start-ups' participation in foreign sales (Cassiman and Golovko, 2011) and for their ability to gain firm-specific advantages in foreign markets. For example, over decades, Israeli startups have relied on the local innovation and global exporting model (Trajtenberg, 2001). Similarly, medical device innovations in the US (Herman et al., 2018), software exports by small firms (Bell, 1995), and design innovation and exports from Italian SMEs (Sterlacchini, 1999) are a few examples of firms relying on innovation as a basis for exporting.

In addition, related industry variety may provide start-ups with access to the knowledge that is needed to modify products under uncertain situations, such as those encountered in international markets (Patel and Vega, 1999), or to adjust their product offerings to the diverse needs of international customers (Yu et al., 2011). As noted by Ganotakis and Love (2012), a venture's ability to enter and succeed in new foreign markets is strongly dependent upon its capacity to adjust its products to meet foreign customers' demands. Accordingly, we hypothesize the following:

Hypothesis 1. The related industry variety in a start-up's location is positively related to the start-up's a) likelihood of exporting and b) persistence in exporting.

\subsection{Unrelated industry variety and start-up internationalization}

Prior research shows that the local spillovers of divergent knowledge sets provide the building blocks for the development of breakthrough solutions and unique products (Castaldi et al., 2015; Phene et al., 2006) because they favor knowledge recombination across cognitively distant domains (Nooteboom et al., 2007). Such innovations may be conducive to the internationalization of start-ups as they push start-ups to internationalize in order to realize the value of such innovations (Autio, 2005). As proposed by Kyläheiko et al. (2011: 509) in an internationalization setting, "the creation of unique superior products [...] enable[s] the incoming firm to overcome the indigenous advantages enjoyed by local firms". These innovations also favor the necessary differentiation in export markets and help identify export niches (Namiki, 1988). Empirical evidence has indeed shown that unique products and breakthrough innovations are important means for start-ups to enter and expand in international markets (Knight and Cavusgil, 2004; Wolff and Pett, 2000). In addition, research shows that innovation prompts exporting when a start-up is able to generate new products or services to create new demands in international markets (Filipescu et al., 2013).

One case at hand is that of the Swedish firm Micronic Laser Systems, located in the Swedish municipality of Täby, which is characterized by firms in multiple and unrelated industries (e.g., electronics, IT, trade, construction and real estate, health, production services). While

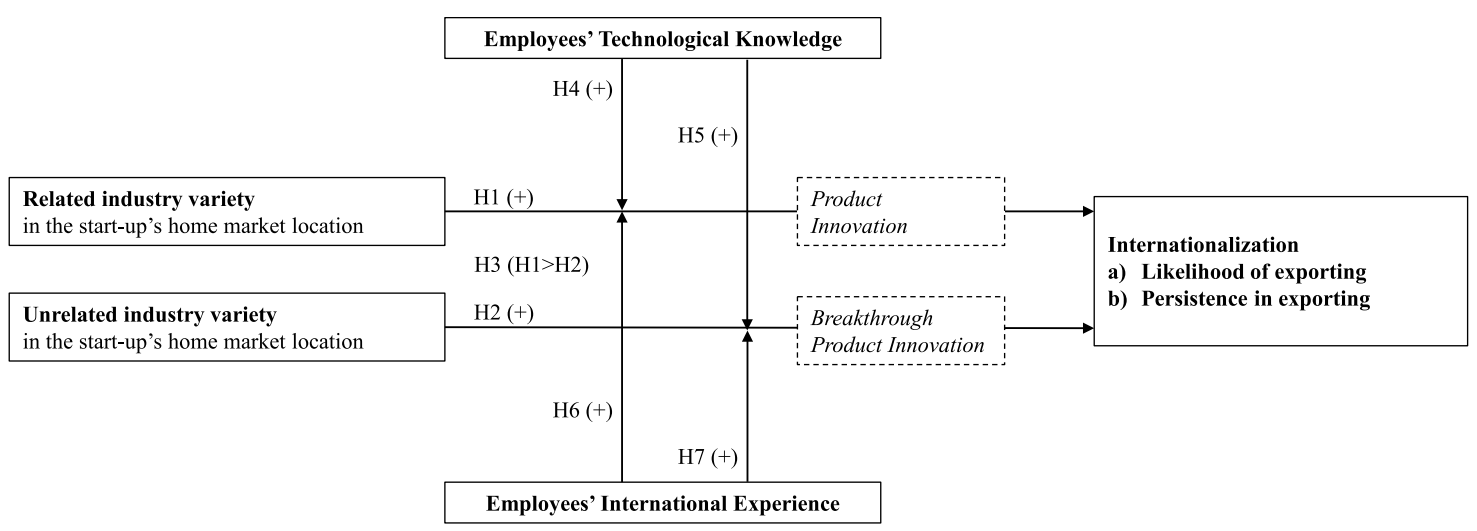

Fig. 1. Conceptual Model Note: The boxes with dashed lines represent the assumed underlying mechanisms. 
Micronic Laser Systems was founded with the idea of using its innovative knowledge in microlithography to serve the semiconductor industry, this start-up seems to have been able to absorb and leverage heterogeneous technological knowledge and substantially redefine its main offering, establishing itself as a world-leading supplier in another business area: the production of laser pattern generators for display systems (source: personal communications, 2004 and 2005). In this global market niche, Micronic Laser Systems' machines have become the de facto industry standard, making the company the industry leader in several countries (Olausson and Berggren, 2010). Based on the above arguments, we expect the following:

Hypothesis 2. Unrelated industry variety in a start-up's location is positively related to the start-up's a) likelihood of exporting and b) persistence in exporting.

\subsection{Related versus unrelated industry variety for start-up internationalization}

While our framework proposes that both related and unrelated industry variety are positively associated with start-up internationalization in terms of both the likelihood of and persistence in exporting, we posit that in general, start-ups derive greater benefits from related industry variety in their home market location than unrelated industry variety to internationalize.

First, it is costlier for start-ups to absorb and recombine unrelated heterogeneous knowledge than related heterogeneous knowledge. Start-ups must devote more effort and human resources to assimilate and recombine broad technological knowledge that is unrelated to their knowledge base (Cohen and Levinthal, 1990). Research argues that the broader the scope of the knowledge to be integrated, the higher are the organizational costs of managing such integration (Grant, 1996), including difficulties in interpretations (Baum et al., 2000) and substantial changes within and outside the organization (Nonaka and Teece, 2001). These costs may limit the likelihood of start-up internationalization (Kumar, 2009).

Second, when absorbing and recombining heterogeneous knowledge from technologically distant fields-such as knowledge spillovers from unrelated industries (Nooteboom et al., 2007)—start-ups face higher uncertainty, making the successful recombination of such distant knowledge challenging (Yang et al., 2010). This effect is well documented in the innovation literature based on patent relatedness (Fleming, 2001). As summarized by Katila and Ahuja (2002: 1185), innovation projects in which the proportion of unrelated knowledge is high are "less likely to succeed than projects that search closely related knowledge". Absorbing local knowledge from a variety of unrelated areas may also lead to erroneous learning, when start-ups make erroneous connections based on that knowledge (Dencker et al., 2009; Levitt and March 1988). Additionally, knowledge may also not transfer well (Baum et al., 2000). For example, the recombination of local knowledge from a variety of unrelated industries might lead firms to underestimate the knowledge gaps that must be bridged to successfully enter and expand in a foreign market (Petersen et al., 2008; Welch and Welch, 2009). Thus, the risky nature of products that originate from the recombination of unrelated knowledge may limit the persistence of a start-up in export markets. With failed products, start-ups might have to completely withdraw from export markets and, in most cases, incur substantial costs. Bingham and Davis (2012) study of nine entrepreneurial firms documents how making weak causal inferences based on distant observations of others' behaviors can result in incomplete and even inaccurate understandings, which can lead to lower performance in international market entry.

In contrast, the recombination of knowledge spilling over from a variety of co-located firms in related industries is more efficient (Yang et al., 2010) and the outcome is less uncertain because relatedness typically allows for a better understanding of the complexities of multiple and unrelated areas of knowledge as well as of the applicability of knowledge to a firm's unique circumstances (Shenkar and $\mathrm{Li}$, 1999). The lower benefits of unrelated local variety to the internationalization of start-ups are confirmed by Antonietti and Cainelli (2011), who show that export intensity tends to be lower for firms in locations characterized by unrelated industry variety. Altogether, these arguments suggest the following:

Hypothesis 3. Compared to unrelated industry variety, related industry variety in a start-up's location has a stronger positive relationship with the start-up's a) likelihood of exporting and b) persistence in exporting.

\subsection{The moderating role of human resources}

In Hypothesis 3, we proposed that unrelated industry variety in a start-up's home location may be less beneficial for the start-up's internationalization than related industry variety because of the higher costs in terms of time, effort and uncertainty in recombining the knowledge spillovers from co-located firms in a variety of unrelated industries. However, we contend that start-ups can reduce recombination costs and uncertainty and use the technological knowledge spilling over (also from unrelated industry variety) when they are endowed with human resources that have high levels of knowledge and experience-which are key features of a firm's absorptive capacity. As explained by Minbaeva et al. (2003: 589) "employees' ability, their educational background, and acquired job-related skills" represent the prior knowledge "which the organization needs to assimilate and use external knowledge". Shane (2000) notes that the stock of a start-up's knowledge and experience influences its ability to search for, comprehend, extrapolate, interpret, and apply new information in novel ways. In line with this notion, and specific to the case of firms benefitting from externalities from co-located firms, Crescenzi and Gagliardi (2018) show that innovation benefits are highly heterogeneous and may depend on firms' capacity to leverage locally sourced knowledge. In this study, we propose two attributes of a start-up's human resources that are critical for absorbing and leveraging local knowledge to internationalize: technological knowledge and international experience.

The technological knowledge of a start-up's employees (including the founder) is essential for the firm to refine, reconfigure, combine and transform local spillovers into knowledge resources to meet foreign market needs (Danneels, 2002; Gruber et al., 2008) and survive (Gimmon and Levie, 2010). Gruber et al. (2013: 297) highlight that "technological experience can be seen as an important ingredient of the venture's absorptive capacity" (Cohen and Levinthal, 1990). Specifically, they argue that start-ups with greater technological experience and associated knowledge have a greater capacity to absorb, assimilate and apply distant knowledge. Proposing the role of technology leveraging and considering the work of Danneels (2002), Gruber and colleagues suggest a two-step approach where in the first step, technological knowledge is needed to understand both generic and specific as well as tangible and intangible knowledge components. The second step "requires the application of the firm's technological resources to new products that address new customers and their needs ('relinking')" (Gruber et al., 2013: 283). Here, the international experience of a startup's employees might be critical (Bloodgood et al., 1996; Madsen and Servais, 1997). International experience helps a start-up develop products that address international customers' needs because the start-up possesses local knowledge and information on local customers, local partners and distribution networks ( $\mathrm{Lu}$ et al., 2014). Based on this reasoning, while the technological knowledge of a start-up's employees provides a solid base for the firm to develop a sense of knowledge components of the knowledge variety in the home location, international market experience is helpful for relinking, that is, applying this knowledge to new products that serve the needs of international customers. Therefore, we posit that prior technological knowledge and international experience-in addition to having a direct effect on the 
internationalization of start-ups-play a critical moderating role, influencing the relationship between related and unrelated industry variety and the internationalization of start-ups. Prior studies provide ample evidence of the direct effects of human resources on start-ups' internationalization. Highlighting the value of employees in internationalization efforts, Stoian et al. (2018) find that tacit knowledge of the products, industries, and markets of international actors, along with functional knowledge, is central to the internationalization of new ventures. Taking a broader perspective of knowledge intensity in internationalization, a meta-analysis Schwens et al. (2018) reveals that knowledge intensity improves internationalization speed, whereas a bibliometric study further highlights the value of knowledge-based resources in international new venture studies (Rodríguez-Ruiz et al., 2019).

\subsubsection{Technological knowledge and related industry variety}

Having prior technological knowledge may help start-ups better assess the international potential of novel products that originate from the recombination of related knowledge areas (Bruneel et al., 2010). Shepherd and DeTienne (2005) hold that individuals with prior knowledge are likely to focus on the most important dimensions of available information and process this information more quickly and reliably; such knowledge could have a greater influence on start-up internationalization as employees with technological knowledge can better parse through and identify recombination opportunities and novel products from related knowledge domains. Supporting these arguments, Zahra et al. (2003) show that the benefits of network relationships in the home market are amplified when start-ups have technological resources because these resources increase these firms' ability to leverage network relationships and develop novel products that international customers value.

Technological knowledge can also assist start-ups by enabling them to streamline their operational efficiency and thus to export novel products that originate from the recombination of related knowledge areas without incurring substantially higher costs than when operating in domestic markets (Knight and Cavusgil, 2004; Yu et al., 2011). Based on the above arguments, we expect the following:

Hypothesis 4. Employees' technological knowledge strengthens the positive relationship between related industry variety and a start-up's a) likelihood of exporting and $b$ ) persistence in exporting.

\subsubsection{Technological knowledge and unrelated industry variety}

Because incoming knowledge and information from firms in multiple unrelated industries often require divergent interpretations and complex adaptations (Baum et al., 2000), the ability to process varied and unrelated information through higher levels of technological knowledge could also increase the internationalization of start-ups.

When external knowledge is highly unrelated to a firm's knowledge base, it may require additional efforts by the firm's human resources to expand the loci of new knowledge combinations (Grabher, 1993). To take advantage of unrelated industry variety, technological knowledge helps start-ups to improve the flow of unrelated knowledge (Barkema and Drogendijk, 2007) and to broker the local knowledge with international market needs (Hargadon and Sutton, 1997), especially in difficult learning environments characterized by increasing unrelated industry variety. Prior technological knowledge can increase cognitive proximity as a start-up is better able to bridge unrelated knowledge domains. Moreover, prior technological knowledge not only can influence a firm's ability to process, absorb and implement external knowledge relevant to internationalizing (Cohen and Levinthal, 1990) but also provides an impetus to acquire less related knowledge (Posen and Chen, 2013). Consequently, start-ups with technological knowledge among its members are more likely to broaden their knowledge search to unrelated domains (Ashby and Goldstein, 2011), helping these start-ups effectively tap into the less related knowledge base of co-located firms to spur internationalization. Taken together, we expect the following:

Hypothesis 5. Employees' technological knowledge strengthens the positive relationship between unrelated industry variety and a start-up's a) likelihood of exporting and $b$ ) persistence in exporting.

\subsubsection{International experience and related industry variety}

The international experience that a start-up's employees acquired during previous employment in international firms forms an important basis for helping the start-up benefit from related industry variety and develop new products that suit the needs of international customers. Internationally experienced members of a start-up may already have access to contacts and information in foreign markets, allowing the firm to adapt/alter its product offering (Vahlne and Bhatti, 2019), to target the appropriate group of foreign-based customers (Filatotchev et al., 2009) and to better identify the "knowledge gaps" that must be bridged to enter and expand in foreign markets (Petersen et al., 2008; Welch and Welch, 2009). Because of their better knowledge and understanding of business practices in foreign markets, start-ups with internationally experienced employees can also devise specific strategies to penetrate foreign markets (Wu and Salomon, 2016) and to defend their novel products from imitation in such markets (Ghemawat, 2007), increasing the odds of long-term success in international markets (Sui and Baum, 2014). Based on the above arguments, we expect the following:

Hypothesis 6. Employees' international experience strengthens the positive relationship between related industry variety and a start-up's a) likelihood of exporting and $b$ ) persistence in exporting.

\subsubsection{International experience and unrelated industry variety}

Having international experienced employees may also help start-ups better assess the international market potential of unique products originating from the recombination of unrelated knowledge (Bruneel et al., 2010). As noted, the market potential of such recombination is very uncertain. Start-ups with greater international experience are more likely to capitalize on existing business and social networks and thus are better able to effectively assess the risks of foreign projects that combine unrelated knowledge domains (Ganotakis and Love, 2012). In a recent study on the relationship between start-ups' prior experience and risky opportunities, Dencker et al. (2009) provide evidence of the benefits of having prior (contextual) experience when exploiting high-risk opportunities.

Second, international experience provides international market knowledge that is needed to best take advantage of breakthrough products, which result from the recombination of unrelated technological knowledge. Without such knowledge, start-ups could risk missing out on opportunities to leverage unique products or technologies in international markets. Consider again the example of Micronic Laser Systems. In an interview, the company's founder commented on the early internationalization of the firm in the 1990s, when the company was seeking customers for its very novel product: a laser pattern generator for display systems. After firm members attended a trade fair, the firm received faxes and few phone calls. The communication was for the most part in Korean, and the members of the start-up had no experience in developing relationships with potential international partners from Korea. Thus, it took time for the firm to follow up on the requests, thus risking missing out on a very important business relationship. This would have endangered the entire internationalization of Micronic because a request led to one of Micronic's major business partners in Asia: LG (source: personal communication, April 2005). Based on the above arguments, we expect the following:

Hypothesis 7. Employees' international experience strengthens the positive relationship between unrelated industry variety and a start-up's a) likelihood of exporting and $b$ ) persistence in exporting. 


\section{Data and methods}

\subsection{Sampling process}

To test the proposed hypotheses, we merged three longitudinal databases maintained by the Swedish Central Bureau of Statistics (SCB): RAMS, which contains yearly data on all registered firms and establishments in Sweden; SCB's exporter register, which provides yearly customs data on all firms registered in Sweden; and LISA, which provides yearly data on all employed individuals in Sweden. To limit single-cohort bias, we selected all start-ups that were established between 2002 and 2005 (Huyghebaert and Van de Gucht, 2004). We tracked these firms from the year of the establishment until 2010.

Consistent with previous research, we limited the sample to startups in the manufacturing sector (Qian et al., 2010). We also excluded firms owned by a foreign company or by a business group (Mudambi and Zahra, 2007) because foreign ownership has been shown to indirectly impact new ventures' human resources (Teixeira and Tavares-Lehmann, 2014). We also excluded firms with more than 10 employees at founding as such firms may be divestitures or spinoffs. Finally, we excluded multi-establishment firms from our sample. The first sample, used to test the likelihood of exporting, contains 26,813 firm-year observations from 3686 start-ups. The second sample, used to test the export persistence, includes only ventures that exported at least one year during the observation period and contains 3007 firm-export spell-year observations from 784 start-ups.

\subsection{Variables}

\subsubsection{Dependent variables}

We used the SCB's exporter register dataset to operationalize our dependent variables.

Likelihood of Exporting. In line with prior research, we tested for the likelihood of exporting using a dichotomous variable taking the value of 1 if the start-up exported in year $t$ and 0 if otherwise.

Persistence in Exporting. In accordance with prior research (see, e.g., Esteve-Pérez et al., 2007; Love and Máñez, 2019; Sui and Baum, 2014), persistence in exporting was not measured directly (in terms of the number of years of continuous exporting) but rather consisted of a binary variable taking the value of 0 as long as the firm remained exporting and the value of 1 when the firm stopped exporting. We used one year as the primary time unit. Start-ups that exported during the last year of observation in our data were considered rightcensored. The average duration of an export spell in our sample is approximately 3 years.

\subsubsection{Independent variables}

We used the RAMS dataset to operationalize our independent variables.

Related and Unrelated Industry Variety. In accordance with previous studies (e.g., Antonietti and Cainelli, 2011), we calculated entropy-based measures of industry variety. Both industry variety variables were calculated for municipality $i$ and year $t$. Unrelated variety in industries measured the distribution of establishments ${ }^{2}$ between twodigit SNI (Swedish Standard Industrial Classification) industries, which is the Swedish version of the Standard Industrial Classification (SIC). Using the entropy approach, unrelated industry variety (UIV) was calculated as follows:

\footnotetext{
${ }^{2}$ We used establishments as our unit of analysis to acknowledge that one large firm may be in different technological domains through different establishments. This approach is finer-grained than that in similar studies using the enterprise as the unit of analysis (Aarstad et al., 2016).
}

$U I V=-\sum_{g=1}^{G} E_{g} \ln E_{g}$

where $E_{g}$ represents the share of establishments in the two-digit industry $g$. UIV ranges from 0 to $\ln G$, where zero variety describes a scenario in which all establishments are in the same 2-digit industry and $\ln G$ variety describes a scenario in which there is equal distribution of establishments over all possible two-digit industries.

To assess related industry variety (RIV), we began by calculating the distribution of establishments among five-digit industries within each two-digit industry as follows:

$H_{g}=-\sum_{i=1}^{I} E_{i g} \ln E_{i g}$

where $E_{i g}$ represents the share of establishments in five-digit industry $i$ for each two-digit industry $g$. The interpretation of the calculation is identical to that of Eq. (1), except that variety here is measured within each two-digit industry rather than between the two-digit industries. This implies that zero within-industry variety exists when all establishments in two-digit industry $g$ are in the same five-digit industry $i$, whereas $\ln I$ variety occurs when there is equal distribution of establishments over all possible five-digit industries $i$ (for each two-digit industry $g$ ). The information concerning the degree of within-industry variety for each two-digit industry $g$, i.e., $H_{g}$, is weighted by the relative size of industry $g$. Summing overall $g$ yields the entropy measure for RIV as follows:

$R I V=\sum_{g=1}^{G} E_{g} H_{g}$

Finally, we act in accordance with Bishop and Gripaios (2010), who argue that when conducting an analysis at the industry level, what is relevant is the "relatedness specific to the individual sector under consideration" (p. 449) which in our case is the manufacturing sector. Moreover, we used a finer-grained approach by calculating industry variety at the industry-municipality level.

The distributions of our industry variety variables over municipalities are illustrated in Fig. 2. The values are the average municipality value during 2002-2010. In our empirical context, the maximum attainable value for UIV is $\ln (23)=3.135$ given that the two-digit number for manufacturing industries is 23 . The UIV variable in our sample ranges from 1.480 to 2.757 with a mean of 2.384; this implies that most municipalities have a diversified manufacturing industry composition at this level of aggregation. In regard to URV, the maximum attainable value differs across two-digit industries and is calculated as follows: $\sum_{g=1}^{G} E_{g} \ln \left(I_{g}\right)$, where $E_{g}$ represents the share of establishments in the two-digit industry $g$ and $I_{g}$ represents the maximum number of five-digit industries in two-digit industry $g$. As such, it is challenging to calculate an overall attainable maximum value without imposing assumptions on the structure of the industries.

\subsubsection{Moderating variables}

We used the LISA dataset to operationalize our moderating variable related to technological knowledge. The LISA dataset includes information about individuals' occupations in their current and previous organizations as well as the education of such individuals. To operationalize our moderating variable related to international experience, instead, we combined the SCB's exporter register and LISA dataset.

Employees' Technological Knowledge. We assessed employees' technological knowledge by looking at whether the employees of a startup (including the founder) obtained a formal degree in technology and manufacturing. ${ }^{3}$ Due to the high skewness, we transformed this variable

\footnotetext{
${ }^{3}$ This measure is based on the "Utbildningsgrupp högsta utbildning" variable, code 55, and it includes the following degrees: architect and training landscape
} 

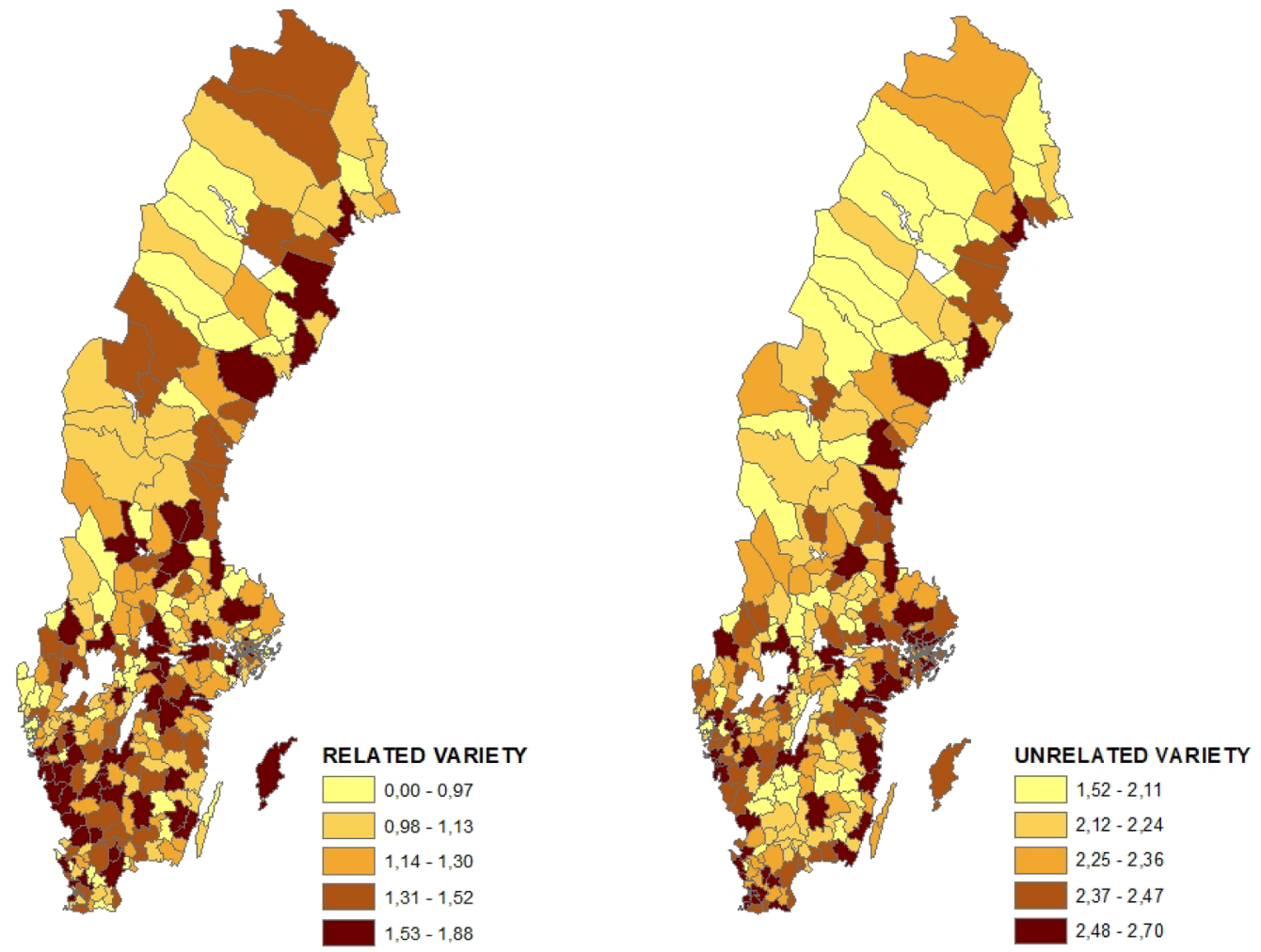

Fig. 2. Distribution of industry variety variables over Swedish municipalities (average value during 2002-2010).

into a dichotomous variable taking the value of 1 if at least one employee had a formal degree in technology and manufacturing and 0 if none of the employees had such a degree.

Employees' International Experience. We assessed employees' international experience by looking at whether the employees of a start-up (including the founder) were working in an international firm, i.e., a Swedish firm with foreign sales activities, in $t-1$. Due to the high skewness, we transformed this variable into a dichotomous variable taking the value of 1 if at least one employee had international experience in $t-1$ and 0 if none of the employees had international experience in $t-1$.

\subsubsection{Control variables}

We use a number of industry-related and firm-specific controls. In both models examining the likelihood of exporting and export persistence, we controlled for industry complexity (inverse of Herfindahl's index as a measure of the concentration of sales in an industry by summing the square of sales market share in a two-digit SNI sector), industry export orientation (the natural logarithm of the sum of firms' export sales in a two-digit SNI sector), cluster location quotient (the degree of cluster-same two-digit SNI sector-employment in the municipality where the start-up is located compared to what exists in Sweden at large). We also controlled for certain firm-level

\section{(footnote continued)}

(55A); master of science in road and water, building, surveying (55C); master of science in machine, vehicle / craft, industrial economy (55D); master of science in electro-technology, technical physics and data (55E); master of science in chemical and biotechnology, material and rock technology (55F); other master of science in engineering and manufacturing (55G); road and aquaculture, surveying engineering $(55 \mathrm{H})$; machine, vehicle / craft, industrial economy engineering (55I); electrical technical physics and data engineering (55J); chemical and biotechnology, material and rock technology engineering (55K); other engineering (55L); and other post-secondary education in technology and manufacturing (55X). characteristics, specifically firm size (the natural logarithm of the number of employees), firm age (the natural logarithm of the age of the firm), firm productivity (value added divided by number of employees), and firm performance aspiration (firm performance in $t-1$ minus competitors' average performance in $t$-2) (see Baum and Dahlin, 2007). Finally, in the model examining export persistence, we controlled for repeated internationalization, i.e., the number of export spells the firm undertook before the current one (Love and Máñez, 2019), age at first internationalization, measured by the age at which the firm initiated exporting (Autio et al., 2000), and the institutional distance 4 between Sweden and the countries to which the firm exported (for start-ups exporting to different countries, we used the unweighted mean of this score). In our analyses, we also controlled for cohort, industry, location $^{5}$ and year dummies.

\subsection{Analytical strategy}

\subsubsection{Sample selection}

In our analysis, we estimate the impact of different covariates on the

\footnotetext{
${ }^{4}$ Following Cezar and Escobar (2015), we used four indicators that measure the quality of governments and their policies: corruption index, government effectiveness, political stability, and regulatory quality. The first captures the extent to which public power is exercised for private gain. The second is sensitive to the quality of public services, their independence from political pressure and the credibility of government commitments. Political stability refers to views about the probability that a government could be destabilized or overthrown by unconstitutional or violent means. The final indicator measures the government's ability to formulate and implement policies and regulations that promote the development of the private sector. These indicators are made available by the World Governance Indicators project of the World Bank. In a principal component factor analysis, all our variables loaded into one factor (Cronbach's $\alpha=0.940$ ).

${ }^{5}$ Stockholm, Malmo, Goteborg, Nacka, Uppsala, Linkoping, Norrkoping and Helsingborg.
} 
outcome only for those start-ups that survived during the observation period (Belderbos and Zou, 2007). To empirically control for sample selection, we use a two-stage Heckman (1979) model. The first step of Heckman's sample-selection equation estimates the probability that a start-up survives within the period considered through a probit equation. The selection variable we use is employees' prior local start-up experience (combining the SCB's exporter register and LISA databases), measured as whether at least one employee of the start-up previously owned and ran a firm that had no export activities, i.e., a local business. Indeed, while prior start-up experience engenders start-ups with knowledge of both successful and unsuccessful practices to improve survival odds, there are no specific reasons to believe that past start-up experience devoid of internationalization activities influences the likelihood that start-ups export.

Our data corroborate this reasoning. Indeed, while the correlation between prior local start-up experience and survival is positive and statistically significant (coef. $=0.046, p<0.05$ ), there is a non-statistically significant correlation between prior local start-up experience and the likelihood of exporting (coef. $=-0.001, p>0.05$ ). We thus regress prior local start-up experience on our selection variable, i.e., the likelihood of survival. Finally, we generate an inverse Mills ratio $\left(\lambda_{s}\right)$ from the probit estimates and control for this score in our main model.

\subsubsection{Model specification}

To model the first dependent variable, i.e., the likelihood of exporting, and to test Hypotheses 1a-7a, we use a random-effects logit model that fits well with the panel nature of our sample.

To model the second dependent variable, i.e., persistence in exporting, and to test Hypotheses $1 \mathrm{~b}-7 \mathrm{~b}$, we use a Cox proportional hazards model (Sui and Baum, 2014). In this analysis, our unit of observation is the export spell, defined as the number of consecutive years of exporting. A spell is computed as starting in year $t$ if the firm did not export in year $t-1$ but exported in year $t$. Similarly, a spell is considered to end the first year in which the firm discontinued exporting. Therefore, this technique helps model export persistence as the length of continuous exporting so that the duration of an exporting spell captures persistence in exporting.

\section{Results}

The correlations, means and standard deviations of the variables for the full sample are presented in Table 1 . The correlations, means and standard deviations of the variables for the sub-sample, i.e., exporting start-ups, are presented in Table 2.

Table 3 shows the results for the hypotheses on the likelihood of exporting, whereas Table 4 shows the results for the hypotheses on persistence in exporting. In Table 4, in line with our modeling, positive coefficients, implying an increase in the hazard of discontinuing exporting, indicate a decrease in the duration of an export spell, i.e., a decrease in persistence, whereas negative coefficients, implying a decrease in the hazard of discontinuing exporting, indicate an increase in the duration of an export spell, i.e., an increase in export persistence.

Model 1 in Tables 3 and 4 includes the control variables; the independent variables are introduced in Model 2. Model 2 in Table 3 shows that related industry variety is positively and statistically significantly related to the likelihood of exporting (Hypothesis 1a: coef. $=0.246, p<0.05$; supported), whereas unrelated industry variety is statistically insignificantly related to export persistence. The $t$-test suggests that there is a statistically significant difference between the two coefficients ${ }^{6}$ (Hypothesis 3a: $\chi^{2}=7.04, p=0.0079$; supported); this suggests that related variety has a greater positive effect on the likelihood of exporting than unrelated industry variety. Model 2 in Table 4 shows that related industry variety is positively and statistically

\footnotetext{
${ }^{6}$ We standardize both industry variety measures.
}

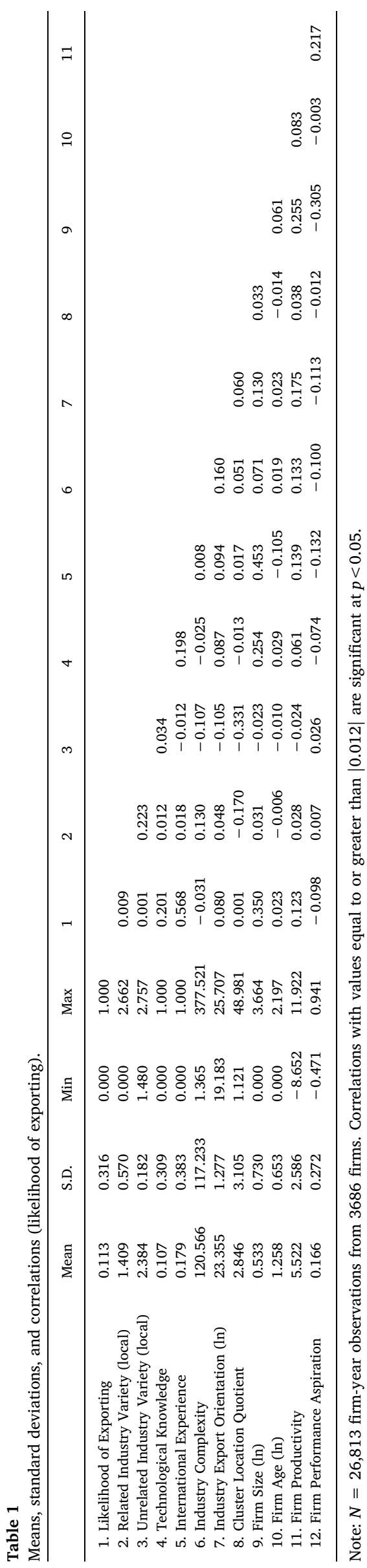


significantly related to export persistence (Hypothesis 1b: coef. $=-0.134, p<0.05$; supported), whereas unrelated industry variety is statistically insignificantly related to export persistence. The $t$ test suggests that there is a statistically significant difference between the two coefficients (Hypothesis $3 \mathrm{~b}: \chi^{2}=4.06, p=0.0440$; supported); this suggests that related variety has a greater positive effect on export persistence than unrelated industry variety.

In Model 3, we enter employees' technological knowledge and international experience variables. Both variables have a positive and statistically significant impact on the likelihood of exporting (coef. $=0.620, p<0.001$ and coef. $=1.253, p<0.001$, respectively), but only international experience has a positive and statistically significant impact on export persistence (coef. $=-0.293, p<0.05$ ). These results are in line with prior studies in the literature that show founders' and managers' prior knowledge and experience to be positively related to their start-ups' early internationalization (Keupp and Gassmann, 2009; Zander et al., 2015).

In Model 4, we test the interaction effect between technological knowledge and related industry variety on the likelihood of (Hypotheses 4a) and persistence in exporting (Hypotheses 4b). The results in Tables 3 and 4 show that the interactions are statistically insignificant.

Model 5 instead tests the interaction effect between technological knowledge and unrelated industry variety on the likelihood of (Hypotheses 5a) and persistence in exporting (Hypotheses 5b). The results in Tables 3 and 4 show that the interactions are positive and statistically significant (Hypothesis $5 \mathrm{a}$ : coef. $=0.325, p<0.05$; supported; Hypothesis 5b: coef. $=-0.249, p<0.05$; supported). These results suggest that the local unrelated industry variety in their home market location fosters start-ups' likelihood and persistence in exporting when start-ups' employees possess technological knowledge, thus corroborating Hypotheses $5 \mathrm{a}$ and $5 \mathrm{~b}$. The interactions were plotted using Zelner (2009) approach, with a logit specification and robust standard errors. Fig. 3a shows that the relationship between unrelated industry variety and the likelihood of exporting goes from being negative when employees have no technological knowledge to being slightly positive when employees have technological knowledge. Fig. $3 \mathrm{~b}$ shows the values of unrelated industry variety where the difference between the two curves is statistically significant (95 percent confidence intervals). Fig. 4a instead shows that the relationship between unrelated industry variety and persistence in exporting goes from being negative when there is no technological knowledge to being positive when there is technological knowledge. Fig. 4b shows the values of unrelated industry variety where the difference between the two curves is statistically significant.

In Model 6, we test the interaction effect between international experience and related industry variety on the likelihood of (Hypotheses 6a) and persistence in exporting (Hypotheses 6b). Model 6 in Table 3 shows that the interaction is statistically insignificant. Model 6 in Table 4 instead shows that the interaction has a positive and statistically significant association with export persistence (Hypothesis 6b: coef. $=-0.160, p<0.05$; supported). These results suggest that local industry-related variety in the home market location further enhances start-ups' export persistence when start-ups' employees possess international experience, thus corroborating Hypothesis 6b. Fig. 5a shows that the positive relationship between related industry variety and persistence in exporting strengthens when employees have international experience. Fig. $5 \mathrm{~b}$ shows the values of related industry variety where the difference between the two curves is statistically significant.

Finally, in Model 7, we test the interaction effect between international experience and unrelated industry variety on the likelihood of (Hypotheses 7a) and persistence in exporting (Hypotheses 7b). The results in Tables 3 and 4 show that these interactions are statistically insignificant. Overall, Hypotheses $1 \mathrm{a}, 1 \mathrm{~b}, 3 \mathrm{a}, 3 \mathrm{~b}, 5 \mathrm{a}, 5 \mathrm{~b}$, and $6 \mathrm{~b}$ are supported. 
Table 3

Industry variety, employees' technological knowledge and international experience, and start-ups' likelihood of exporting.

\begin{tabular}{|c|c|c|c|c|c|c|c|c|}
\hline & Model 1 & Model 2 & Model 3 & Model 4 & Model 5 & Model 6 & Model 7 & Model 8 \\
\hline Inverse Mills Ratio: Survival $\left(\lambda_{s}\right)$ & $\begin{array}{l}2.404^{* *} \\
(0.731)\end{array}$ & $\begin{array}{l}2.362^{* *} \\
(0.732)\end{array}$ & $\begin{array}{l}1.877 * * \\
(0.696)\end{array}$ & $\begin{array}{l}1.879 * * \\
(0.696)\end{array}$ & $\begin{array}{l}1.868^{* *} \\
(0.696)\end{array}$ & $\begin{array}{l}1.878 * * \\
(0.696)\end{array}$ & $\begin{array}{l}1.873^{* *} \\
(0.696)\end{array}$ & $\begin{array}{l}1.866^{* *} \\
(0.697)\end{array}$ \\
\hline Industry Complexity & $\begin{array}{l}0.003 \\
(0.002)\end{array}$ & $\begin{array}{l}0.003 \\
(0.002)\end{array}$ & $\begin{array}{l}0.003^{*} \\
(0.002)\end{array}$ & $\begin{array}{l}0.003^{*} \\
(0.002)\end{array}$ & $\begin{array}{l}0.003 * \\
(0.002)\end{array}$ & $\begin{array}{l}0.003 * \\
(0.002)\end{array}$ & $\begin{array}{l}0.003^{*} \\
(0.002)\end{array}$ & $\begin{array}{l}0.003^{*} \\
(0.002)\end{array}$ \\
\hline Industry Export Orientation (ln) & $\begin{array}{l}0.053 \\
(0.248)\end{array}$ & $\begin{array}{l}0.038 \\
(0.247)\end{array}$ & $\begin{array}{l}0.109 \\
(0.221)\end{array}$ & $\begin{array}{l}0.107 \\
(0.221)\end{array}$ & $\begin{array}{l}0.105 \\
(0.222)\end{array}$ & $\begin{array}{l}0.108 \\
(0.221)\end{array}$ & $\begin{array}{l}0.109 \\
(0.221)\end{array}$ & $\begin{array}{l}0.105 \\
(0.222)\end{array}$ \\
\hline Cluster Location Quotient & $\begin{array}{l}-0.005 \\
(0.019)\end{array}$ & $\begin{array}{l}-0.010 \\
(0.020)\end{array}$ & $\begin{array}{l}-0.011 \\
(0.018)\end{array}$ & $\begin{array}{l}-0.011 \\
(0.018)\end{array}$ & $\begin{array}{l}-0.010 \\
(0.018)\end{array}$ & $\begin{array}{l}-0.011 \\
(0.018)\end{array}$ & $\begin{array}{c}-0.011 \\
(0.018)\end{array}$ & $\begin{array}{l}-0.010 \\
(0.018)\end{array}$ \\
\hline Firm Size (ln) & $\begin{array}{l}1.797^{* * *} \\
(0.106)\end{array}$ & $\begin{array}{l}1.789 * * * \\
(0.106)\end{array}$ & $\begin{array}{l}1.400 * * * \\
(0.098)\end{array}$ & $\begin{array}{l}1.400 * * * \\
(0.098)\end{array}$ & $\begin{array}{l}1.402^{* * *} \\
(0.098)\end{array}$ & $\begin{array}{l}1.400 * * * \\
(0.098)\end{array}$ & $\begin{array}{l}1.401^{* * *} \\
(0.098)\end{array}$ & $\begin{array}{l}1.403^{* * *} \\
(0.098)\end{array}$ \\
\hline Firm Age (ln) & $\begin{array}{l}-0.036 \\
(0.271)\end{array}$ & $\begin{array}{c}-0.031 \\
(0.270)\end{array}$ & $\begin{array}{l}0.096 \\
(0.238)\end{array}$ & $\begin{array}{l}0.098 \\
(0.238)\end{array}$ & $\begin{array}{l}0.095 \\
(0.238)\end{array}$ & $\begin{array}{l}0.096 \\
(0.238)\end{array}$ & $\begin{array}{l}0.096 \\
(0.238)\end{array}$ & $\begin{array}{l}0.096 \\
(0.238)\end{array}$ \\
\hline Firm Productivity & $\begin{array}{l}0.155^{* * *} \\
(0.035)\end{array}$ & $\begin{array}{l}0.155^{* * *} \\
(0.035)\end{array}$ & $\begin{array}{l}0.152^{* * * *} \\
(0.032)\end{array}$ & $\begin{array}{l}0.152^{* * *} \\
(0.032)\end{array}$ & $\begin{array}{l}0.152^{* * *} \\
(0.032)\end{array}$ & $\begin{array}{l}0.153^{* * *} \\
(0.032)\end{array}$ & $\begin{array}{l}0.153^{* * *} \\
(0.032)\end{array}$ & $\begin{array}{l}0.152^{* * *} \\
(0.032)\end{array}$ \\
\hline Firm Performance Aspirations & $\begin{array}{l}-2.555^{* * *} \\
(0.382)\end{array}$ & $\begin{array}{l}-2.562^{* * *} \\
(0.379)\end{array}$ & $\begin{array}{l}-2.268^{* * *} \\
(0.325)\end{array}$ & $\begin{array}{l}-2.263^{* * *} \\
(0.326)\end{array}$ & $\begin{array}{l}-2.269^{* * *} \\
(0.326)\end{array}$ & $\begin{array}{l}-2.267^{* * *} \\
(0.325)\end{array}$ & $\begin{array}{l}-2.268^{* * *} \\
(0.325)\end{array}$ & $\begin{array}{l}-2.268^{* * *} \\
(0.327)\end{array}$ \\
\hline Related Industry Variety (local) & & $\begin{array}{l}0.246^{*} \\
(0.103)\end{array}$ & $\begin{array}{l}0.234^{*} \\
(0.093)\end{array}$ & $\begin{array}{l}0.217^{*} \\
(0.097)\end{array}$ & $\begin{array}{l}0.235^{*} \\
(0.092)\end{array}$ & $\begin{array}{l}0.225^{*} \\
(0.099)\end{array}$ & $\begin{array}{l}0.233^{*} \\
(0.093)\end{array}$ & $\begin{array}{l}0.228^{*} \\
(0.102)\end{array}$ \\
\hline Unrelated Industry Variety (local) & & $\begin{array}{l}-0.156 \\
(0.083)\end{array}$ & $\begin{array}{l}-0.136 \\
(0.075)\end{array}$ & $\begin{array}{l}-0.137 \\
(0.075)\end{array}$ & $\begin{array}{l}-0.191 * \\
(0.076)\end{array}$ & $\begin{array}{l}-0.136 \\
(0.075)\end{array}$ & $\begin{array}{l}-0.164^{*} \\
(0.081)\end{array}$ & $\begin{array}{l}-0.213^{* *} \\
(0.083)\end{array}$ \\
\hline Technological Knowledge & & & $\begin{array}{l}0.620^{* * *} \\
(0.181)\end{array}$ & $\begin{array}{l}0.613^{* * *} \\
(0.180)\end{array}$ & $\begin{array}{l}0.641^{* * *} \\
(0.181)\end{array}$ & $\begin{array}{l}0.619^{* * * *} \\
(0.181)\end{array}$ & $\begin{array}{l}0.619^{* * *} \\
(0.180)\end{array}$ & $\begin{array}{l}0.639 * * * \\
(0.180)\end{array}$ \\
\hline International Experience & & & $\begin{array}{l}1.253^{* * *} \\
(0.093)\end{array}$ & $\begin{array}{l}1.252^{* * *} \\
(0.093)\end{array}$ & $\begin{array}{l}1.248^{* * *} \\
(0.093)\end{array}$ & $\begin{array}{l}1.253^{* * *} \\
(0.093)\end{array}$ & $\begin{array}{l}1.254^{* * *} \\
(0.094)\end{array}$ & $\begin{array}{l}1.250 * * * \\
(0.094)\end{array}$ \\
\hline Related Industry Variety * Technological Knowledge & & & & $\begin{array}{l}0.102 \\
(0.154)\end{array}$ & & & & $\begin{array}{l}0.017 \\
(0.153)\end{array}$ \\
\hline Unrelated Industry Variety * Technological Knowledge & & & & & $\begin{array}{l}0.325^{*} \\
(0.145)\end{array}$ & & & $\begin{array}{l}0.316^{*} \\
(0.148)\end{array}$ \\
\hline Related Industry Variety * International Experience & & & & & & $\begin{array}{l}0.021 \\
(0.081)\end{array}$ & & $\begin{array}{l}0.007 \\
(0.082)\end{array}$ \\
\hline Unrelated Industry Variety * International Experience & & & & & & & $\begin{array}{l}0.064 \\
(0.076)\end{array}$ & $\begin{array}{l}0.053 \\
(0.077)\end{array}$ \\
\hline Intercept & $\begin{array}{l}-12.470^{*} \\
(5.906)\end{array}$ & $\begin{array}{l}-12.075^{*} \\
(5.891)\end{array}$ & $\begin{array}{l}-12.704^{*} \\
(5.272)\end{array}$ & $\begin{array}{l}-12.662^{*} \\
(5.268)\end{array}$ & $\begin{array}{l}-12.624 * \\
(5.292)\end{array}$ & $\begin{array}{l}-12.700^{*} \\
(5.270)\end{array}$ & $\begin{array}{l}-12.730^{*} \\
(5.268)\end{array}$ & $\begin{array}{l}-12.636^{*} \\
(5.287)\end{array}$ \\
\hline $\ln \left(\sigma_{\nu}^{2}\right)$ & $\begin{array}{l}2.649 * * * \\
(0.084)\end{array}$ & $\begin{array}{l}2.636^{* * *} \\
(0.083)\end{array}$ & $\begin{array}{l}2.211^{* * *} \\
(0.082)\end{array}$ & $\begin{array}{l}2.211^{* * *} \\
(0.082)\end{array}$ & $\begin{array}{l}2.215^{* * *} \\
(0.082)\end{array}$ & $\begin{array}{l}2.210^{* * * *} \\
(0.082)\end{array}$ & $\begin{array}{l}2.211^{* * *} \\
(0.082)\end{array}$ & $\begin{array}{l}2.215^{* * *} \\
(0.082)\end{array}$ \\
\hline Year Dummies & Included & Included & Included & Included & Included & Included & Included & Included \\
\hline Cohort Dummies & Included & Included & Included & Included & Included & Included & Included & Included \\
\hline Industry Dummies & Included & Included & Included & Included & Included & Included & Included & Included \\
\hline Location Dummies & Included & Included & Included & Included & Included & Included & Included & Included \\
\hline Log-likelihood & -4688.14 & -4683.88 & -4590.60 & -4590.29 & -4587.18 & -4590.56 & -4590.23 & -4586.89 \\
\hline Chi2 & 583.90 & 589.59 & 975.20 & 978.29 & 984.39 & 975.79 & 974.69 & 984.11 \\
\hline$N$ & 26,815 & 26,813 & 26,813 & 26,813 & 26,813 & 26,813 & 26,813 & 26,813 \\
\hline Number of Firms & 3686 & 3686 & 3686 & 3686 & 3686 & 3686 & 3686 & 3686 \\
\hline
\end{tabular}

$* p<0.05 ; * * p<0.01 ; * * * p<0.001$.

Note. This table presents the results of a random-effects logit model. Standard errors are clustered at the firm level and are reported in parentheses.

\subsection{Auxiliary analysis}

In the theoretical section of this paper we argue that a start-up's location characterized by related or unrelated industry variety leads to spillovers of heterogeneous knowledge; these spillovers influence the firm's internationalization likelihood and persistence through their effects on the start-up's ability to launch novel solutions and products in international markets (Castaldi et al., 2015). Specifically, we argue that related industry variety spurs internationalization based on product innovation (it provides start-ups with varied and technologically proximate knowledge that might spur innovation), while unrelated industry variety spurs internationalization based on breakthrough product innovation (it provides start-ups with varied and technologically distant knowledge that might lead to breakthrough innovation) (see Fig. 1). Such effects are not observable, but if our arguments hold true, related industry variety should be positively associated with product innovation in export markets, and unrelated industry variety should be positively associated with breakthrough product innovation in export markets; both product innovation and breakthrough product innovation, in turn, should be positively associated with start-ups' export persistence.

To capture the novelty of exported products, we create one proxy for exported product innovation and one for exported breakthrough product innovation. The product innovation variable counts the number of unique-to-the-geographic-market or unique-to-the-industry products (compared to all Swedish exporters) the start-up exports in year $t$ (Besedeš and Prusa, 2011; Cadot et al., 2011). The breakthrough product innovation variable counts the number of unique-to-the-geographicmarket and unique-to-the-industry products (compared to all Swedish exporters) the start-up exports in year $t$ (Azar and Ciabuschi, 2017; Ganotakis and Love, 2010). To obtain a fine-grained measure, we use the 8-digit product code (Combined Nomenclature 8) to define products. As the product innovation and breakthrough product innovation variables can be computed only for exporting start-ups, we run this analysis only in the sub-sample of exporting start-ups.

We test two mediation relationships: a) related industry variety $\rightarrow$ product innovation $\rightarrow$ persistence in exporting and $\mathrm{b}$ ) unrelated industry variety $\rightarrow$ breakthrough product innovation $\rightarrow$ persistence in exporting using Baron and Kenny's (1986) logic because the recent methods to test mediation (Preacher et al., 2007) do not lend themselves to mediation testing in a non-cross-sectional data framework. Essentially, to test for mediation, in step 1, we use the variables in the main model to predict the number of exported products for each year $t$. In step 2, we include these variables in the main model to predict the outcome 
Table 4

Industry variety, employees' technological knowledge and international experience, and start-ups' persistence in exporting.

\begin{tabular}{|c|c|c|c|c|c|c|c|c|}
\hline & Model 1 & Model 2 & Model 3 & Model 4 & Model 5 & Model 6 & Model 7 & Model 8 \\
\hline Industry Complexity & $\begin{array}{l}0.002 \\
(0.002)\end{array}$ & $\begin{array}{l}0.002 \\
(0.002)\end{array}$ & $\begin{array}{l}0.002 \\
(0.002)\end{array}$ & $\begin{array}{l}0.002 \\
(0.002)\end{array}$ & $\begin{array}{l}0.002 \\
(0.002)\end{array}$ & $\begin{array}{l}0.002 \\
(0.002)\end{array}$ & $\begin{array}{l}0.002 \\
(0.002)\end{array}$ & $\begin{array}{l}0.002 \\
(0.002)\end{array}$ \\
\hline Industry Export Orientation (ln) & $\begin{array}{l}0.256 \\
(0.211)\end{array}$ & $\begin{array}{l}0.256 \\
(0.211)\end{array}$ & $\begin{array}{l}0.246 \\
(0.214)\end{array}$ & $\begin{array}{l}0.237 \\
(0.214)\end{array}$ & $\begin{array}{l}0.261 \\
(0.212)\end{array}$ & $\begin{array}{l}0.268 \\
(0.211)\end{array}$ & $\begin{array}{l}0.254 \\
(0.214)\end{array}$ & $\begin{array}{l}0.279 \\
(0.211)\end{array}$ \\
\hline Cluster Location Quotient & $\begin{array}{l}0.014 \\
(0.008)\end{array}$ & $\begin{array}{l}0.014 \\
(0.009)\end{array}$ & $\begin{array}{l}0.014 \\
(0.009)\end{array}$ & $\begin{array}{l}0.013 \\
(0.009)\end{array}$ & $\begin{array}{l}0.015 \\
(0.009)\end{array}$ & $\begin{array}{l}0.013 \\
(0.009)\end{array}$ & $\begin{array}{l}0.014 \\
(0.009)\end{array}$ & $\begin{array}{l}0.014 \\
(0.009)\end{array}$ \\
\hline Firm Size (ln) & $\begin{array}{l}-0.248^{* * * *} \\
(0.050)\end{array}$ & $\begin{array}{l}-0.244^{* * *} \\
(0.050)\end{array}$ & $\begin{array}{l}-0.189^{* * *} \\
(0.053)\end{array}$ & $\begin{array}{l}-0.188^{* * *} \\
(0.053)\end{array}$ & $\begin{array}{l}-0.187^{* * *} \\
(0.053)\end{array}$ & $\begin{array}{l}-0.189^{* * *} \\
(0.052)\end{array}$ & $\begin{array}{l}-0.189^{* * * *} \\
(0.053)\end{array}$ & $\begin{array}{l}-0.187^{* * *} \\
(0.053)\end{array}$ \\
\hline Firm Age (ln) & $\begin{array}{l}0.660^{* * * *} \\
(0.159)\end{array}$ & $\begin{array}{l}0.670^{* * *} \\
(0.160)\end{array}$ & $\begin{array}{l}0.534^{* *} \\
(0.167)\end{array}$ & $\begin{array}{l}0.543^{* *} \\
(0.167)\end{array}$ & $\begin{array}{l}0.534^{* *} \\
(0.168)\end{array}$ & $\begin{array}{l}0.521^{* *} \\
(0.167)\end{array}$ & $\begin{array}{l}0.533^{* *} \\
(0.167)\end{array}$ & $\begin{array}{l}0.525^{* *} \\
(0.167)\end{array}$ \\
\hline Firm Productivity & $\begin{array}{l}-0.016 \\
(0.014)\end{array}$ & $\begin{array}{l}-0.017 \\
(0.015)\end{array}$ & $\begin{array}{l}-0.016 \\
(0.015)\end{array}$ & $\begin{array}{c}-0.016 \\
(0.015)\end{array}$ & $\begin{array}{c}-0.017 \\
(0.015)\end{array}$ & $\begin{array}{l}-0.016 \\
(0.015)\end{array}$ & $\begin{array}{l}-0.017 \\
(0.015)\end{array}$ & $\begin{array}{l}-0.017 \\
(0.015)\end{array}$ \\
\hline Firm Performance Aspirations & $\begin{array}{l}-0.256 \\
(0.207)\end{array}$ & $\begin{array}{l}-0.242 \\
(0.206)\end{array}$ & $\begin{array}{l}-0.260 \\
(0.205)\end{array}$ & $\begin{array}{l}-0.259 \\
(0.205)\end{array}$ & $\begin{array}{l}-0.269 \\
(0.206)\end{array}$ & $\begin{array}{l}-0.260 \\
(0.204)\end{array}$ & $\begin{array}{l}-0.259 \\
(0.205)\end{array}$ & $\begin{array}{l}-0.269 \\
(0.205)\end{array}$ \\
\hline Repeated Internationalization & $\begin{array}{l}-0.622^{* * *} \\
(0.186)\end{array}$ & $\begin{array}{l}-0.637^{* * *} \\
(0.185)\end{array}$ & $\begin{array}{l}-0.549^{* *} \\
(0.182)\end{array}$ & $\begin{array}{l}-0.562^{* *} \\
(0.182)\end{array}$ & $\begin{array}{l}-0.565^{* *} \\
(0.183)\end{array}$ & $\begin{array}{l}-0.543^{* *} \\
(0.182)\end{array}$ & $\begin{array}{l}-0.550 * * \\
(0.182)\end{array}$ & $\begin{array}{l}-0.563^{* *} \\
(0.183)\end{array}$ \\
\hline Age at First Internationalization & $\begin{array}{l}-0.113^{*} \\
(0.051)\end{array}$ & $\begin{array}{l}-0.117^{*} \\
(0.051)\end{array}$ & $\begin{array}{l}-0.093 \\
(0.051)\end{array}$ & $\begin{array}{l}-0.096 \\
(0.051)\end{array}$ & $\begin{array}{l}-0.091 \\
(0.051)\end{array}$ & $\begin{array}{l}-0.091 \\
(0.051)\end{array}$ & $\begin{array}{l}-0.093 \\
(0.051)\end{array}$ & $\begin{array}{l}-0.090 \\
(0.051)\end{array}$ \\
\hline Institutional Distance & $\begin{array}{l}0.134 * * \\
(0.051)\end{array}$ & $\begin{array}{l}0.136^{* * *} \\
(0.052)\end{array}$ & $\begin{array}{l}0.134^{* *} \\
(0.052)\end{array}$ & $\begin{array}{l}0.138^{* *} \\
(0.051)\end{array}$ & $\begin{array}{l}0.133^{*} \\
(0.052)\end{array}$ & $\begin{array}{l}0.133^{* *} \\
(0.052)\end{array}$ & $\begin{array}{l}0.130^{*} \\
(0.052)\end{array}$ & $\begin{array}{l}0.133^{*} \\
(0.052)\end{array}$ \\
\hline Related Industry Variety (local) & & $\begin{array}{l}-0.134 * \\
(0.055)\end{array}$ & $\begin{array}{l}-0.127 * \\
(0.054)\end{array}$ & $\begin{array}{c}-0.102 \\
(0.058)\end{array}$ & $\begin{array}{l}-0.117 * \\
(0.055)\end{array}$ & $\begin{array}{c}-0.044 \\
(0.063)\end{array}$ & $\begin{array}{l}-0.126^{*} \\
(0.054)\end{array}$ & $\begin{array}{l}-0.031 \\
(0.066)\end{array}$ \\
\hline Unrelated Industry Variety (local) & & $\begin{array}{l}0.032 \\
(0.045)\end{array}$ & $\begin{array}{l}0.034 \\
(0.045)\end{array}$ & $\begin{array}{l}0.037 \\
(0.045)\end{array}$ & $\begin{array}{l}0.073 \\
(0.049)\end{array}$ & $\begin{array}{l}0.034 \\
(0.045)\end{array}$ & $\begin{array}{l}0.066 \\
(0.055)\end{array}$ & $\begin{array}{l}0.077 \\
(0.058)\end{array}$ \\
\hline Technological Knowledge & & & $\begin{array}{l}-0.188 \\
(0.103)\end{array}$ & $\begin{array}{l}-0.197 \\
(0.104)\end{array}$ & $\begin{array}{l}-0.192 \\
(0.103)\end{array}$ & $\begin{array}{l}-0.178 \\
(0.103)\end{array}$ & $\begin{array}{c}-0.186 \\
(0.103)\end{array}$ & $\begin{array}{l}-0.186 \\
(0.103)\end{array}$ \\
\hline International Experience & & & $\begin{array}{l}-0.293^{*} \\
(0.126)\end{array}$ & $\begin{array}{l}-0.286^{*} \\
(0.127)\end{array}$ & $\begin{array}{l}-0.286^{*} \\
(0.126)\end{array}$ & $\begin{array}{l}-0.311^{*} \\
(0.126)\end{array}$ & $\begin{array}{l}-0.296^{*} \\
(0.126)\end{array}$ & $\begin{array}{l}-0.301 * \\
(0.126)\end{array}$ \\
\hline Related Industry Variety * Technological Knowledge & & & & $\begin{array}{l}-0.126 \\
(0.088)\end{array}$ & & & & $\begin{array}{l}-0.043 \\
(0.092)\end{array}$ \\
\hline Unrelated Industry Variety * Technological Knowledge & & & & & $\begin{array}{l}-0.249^{*} \\
(0.100)\end{array}$ & & & $\begin{array}{l}-0.230 * \\
(0.106)\end{array}$ \\
\hline Related Industry Variety * International Experience & & & & & & $\begin{array}{l}-0.160 * \\
(0.073)\end{array}$ & & $\begin{array}{l}-0.151^{*} \\
(0.075)\end{array}$ \\
\hline Unrelated Industry Variety * International Experience & & & & & & & $\begin{array}{c}-0.059 \\
(0.074)\end{array}$ & $\begin{array}{l}-0.010 \\
(0.078)\end{array}$ \\
\hline Cohort Dummies & Included & Included & Included & Included & Included & Included & Included & Included \\
\hline Industry Dummies & Included & Included & Included & Included & Included & Included & Included & Included \\
\hline Location Dummies & Included & Included & Included & Included & Included & Included & Included & Included \\
\hline Log-likelihood & -3654.22 & -3652.24 & -3649.03 & -3648.38 & -3646.84 & -3647.33 & -3648.80 & -3645.16 \\
\hline Chi2 & 1262.78 & 1267.01 & 166.03 & 1948.13 & 170.66 & 1628.91 & 1947.38 & 1413.32 \\
\hline$N$ & 3007 & 3007 & 3007 & 3007 & 3007 & 3007 & 3007 & 3007 \\
\hline Number of Internationalization Spells & 980 & 980 & 980 & 980 & 980 & 980 & 980 & 980 \\
\hline Number of Firms & 784 & 784 & 784 & 784 & 784 & 784 & 784 & 784 \\
\hline
\end{tabular}

* $p<0.05 ; * * p<0.01 ; * * * p<0.001$.

Note. This table presents the results of a Cox proportional hazard regression. The coefficients (and not the hazard ratios) are presented. Positive coefficients, implying an increase in the hazard of discontinuing exporting, mean a decrease in the duration of an export spell, i.e., a decrease in persistence, whereas negative coefficients, implying a decrease in the hazard of discontinuing exporting, mean an increase in the duration of an export spell, i.e., an increase in persistence with exporting. Standard errors are clustered at the export-spell level (in parentheses).

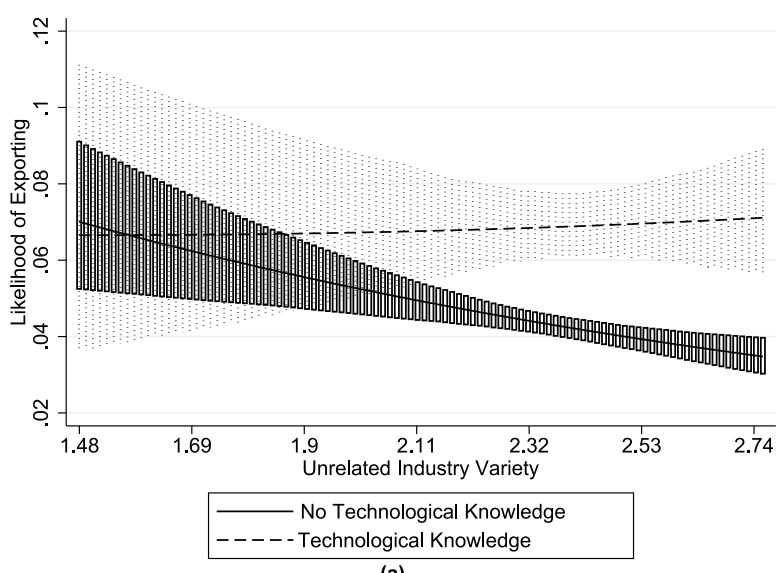

(a)

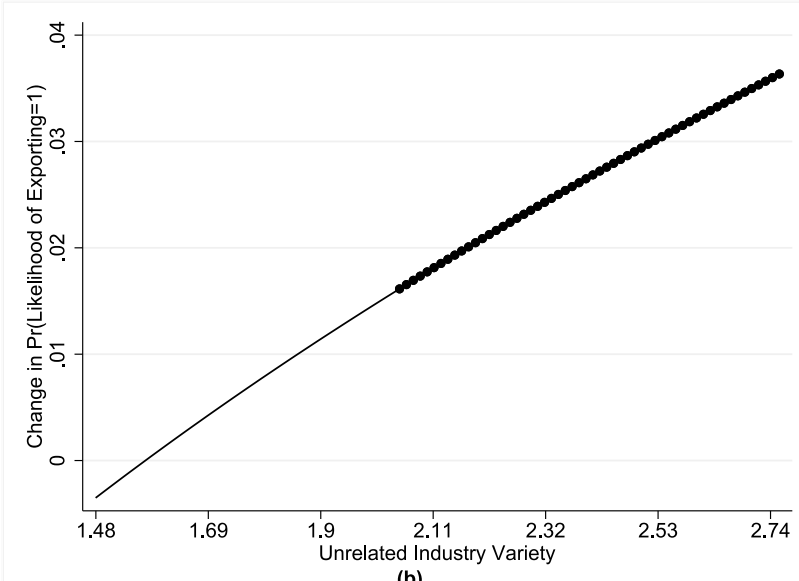

(b)

Fig. 3. Unrelated industry variety (local), employees' technological knowledge and start-ups' likelihood of exporting. 


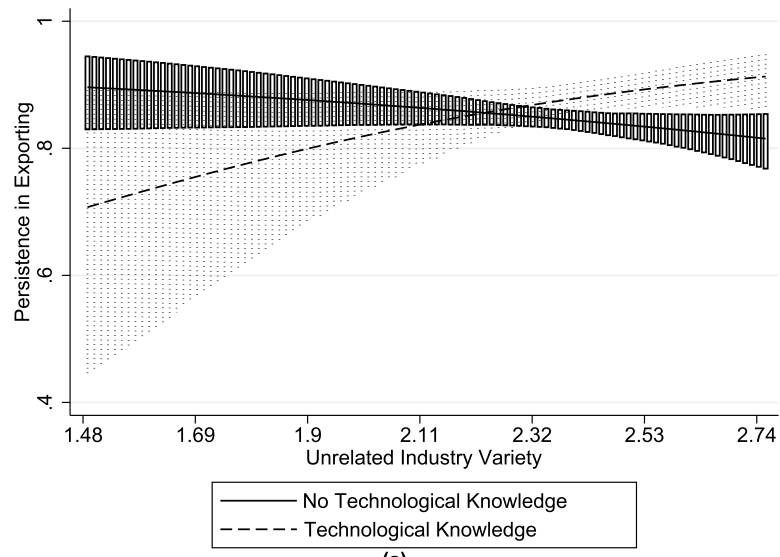

(a)

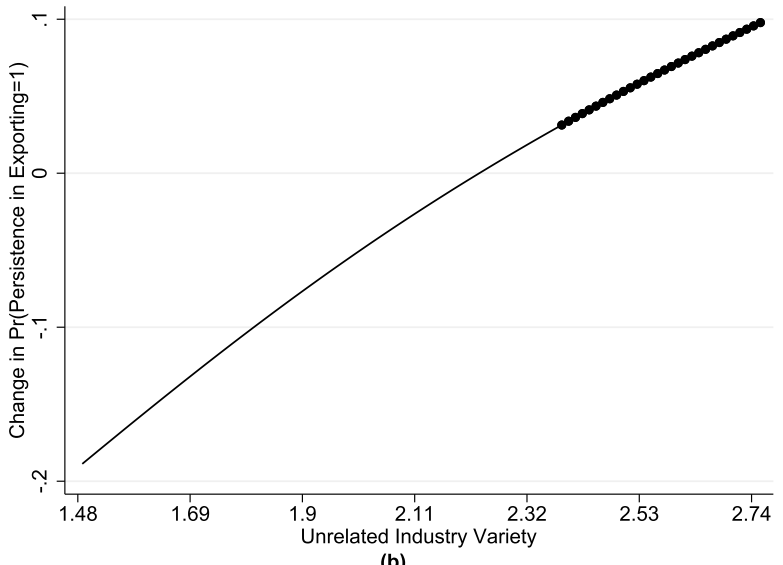

(b)

Fig. 4. Unrelated industry variety (local), employees' technological knowledge and start-ups' persistence in exporting.

variable, i.e., persistence in exporting.

In the first step, we use the industry variety types to predict product innovation and breakthrough product innovation, displayed in Models 1 and 2, respectively, of Table 5. Model 1 shows that both related industry variety (coef. $=0.183, p<0.05$ ) and unrelated industry variety (coef. $=0.116, p<0.05$ ) are positively and significantly related to the number of innovative products. Model 2 instead shows that only unrelated industry variety is positively and significantly related to the number of breakthrough innovative products (coef. $=0.303, p<0.05$ ). These first-step results predicting product innovation as a mediator indicate a positive association between industry variety and a start-up's level of innovation.

In the second step, we include both industry variety types and product innovation types to predict export persistence. If product innovation type is statistically significant but industry variety type is not, then we can infer mediation. Model 1 in Table 6 shows that the number of innovative products has a positive and statistically significant relationship with export persistence (coef. $=-0.335, p<0.001$ ). Model 1 in Table 6 also shows that when we control for the number of innovative products, the relationship between related industry variety and export persistence is statistically insignificant; this supports a full mediation (compare with Model 2 in Table 4). Model 2 in Table 6 shows that the number of breakthrough innovative products has a positive and statistically significant relationship with export persistence (coef. $=-0.157, p<0.01$ ). Moreover, Model 2 in Table 6 shows that when we control for the number of breakthrough innovative products, the relationship between unrelated industry variety and export

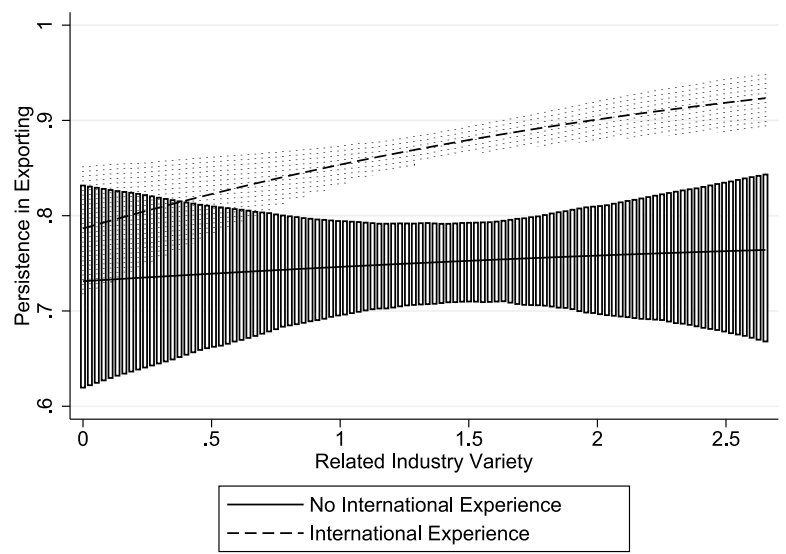

(a) persistence is still statistically insignificant (compare with Model 2 in Table 4), whereas the relationship between related industry variety and export persistence is positive and statistically significant (coef. $=-0.134, p<0.05$ ).

These exploratory results show that the mediation effect for related industry variety through product innovation to internationalization persistence is significant $(p=0.016)$ (based on the Sobel test). However, the effect of unrelated industry variety through product innovation is only marginally significant ( $p=0.057$ ). The effect of unrelated industry variety through breakthrough innovation is also marginally significant $(p=0.059)$. Overall, there is evidence of at least marginally significant mediation effects for the role of innovative products as a channel to improve persistence in internationalization.

\section{Discussion}

The international entrepreneurship literature has highlighted the role of a start-up's geographical location as an important locus for external knowledge sourcing and learning (Fernhaber et al., 2008, 2009; Libaers and Meyer, 2011). Extending this stream of research through the lens of Jacobian externalities in economic geography, our results show that related industry variety in a start-up's location is positively related to the start-up's internationalization-in terms of both its likelihood of and persistence in exporting-while unrelated industry variety does not have a significant direct effect on start-up internationalization; this may be because it is more difficult to benefit from local unrelated knowledge. However, our results also show that a start-

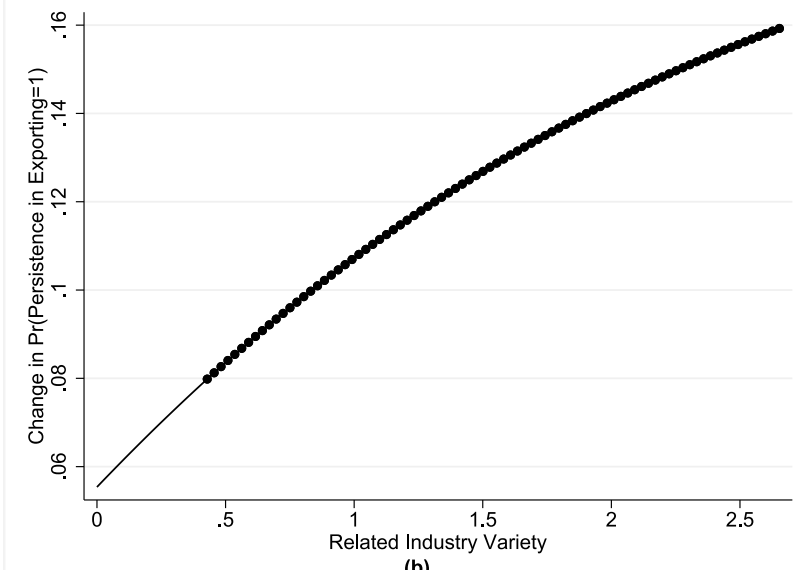

(b)

Fig. 5. Related industry variety (local), employees' international experience and start-ups' persistence in exporting. 
Table 5

Auxiliary analysis - Related and unrelated industry variety and product innovation.

\begin{tabular}{|c|c|c|}
\hline & $\begin{array}{l}\text { Model } 1 \text { (DV= } \\
\text { Product } \\
\text { Innovation) }\end{array}$ & $\begin{array}{l}\text { Model } 2(\mathrm{DV}= \\
\text { Breakthrough Product } \\
\text { Innovation) }\end{array}$ \\
\hline Industry Complexity & $\begin{array}{l}0.001 \\
(0.001)\end{array}$ & $\begin{array}{l}0.001 \\
(0.004)\end{array}$ \\
\hline Industry Export Orientation (ln) & $\begin{array}{l}0.043 \\
(0.135)\end{array}$ & $\begin{array}{l}0.196 \\
(0.345)\end{array}$ \\
\hline Cluster Location Quotient & $\begin{array}{l}0.008 \\
(0.013)\end{array}$ & $\begin{array}{l}-0.005 \\
(0.031)\end{array}$ \\
\hline Firm Size (ln) & $\begin{array}{l}0.252^{* * *} \\
(0.055)\end{array}$ & $\begin{array}{l}0.376^{* *} \\
(0.124)\end{array}$ \\
\hline Firm Age (ln) & $\begin{array}{l}0.231^{* * * *} \\
(0.054)\end{array}$ & $\begin{array}{l}-0.018 \\
(0.117)\end{array}$ \\
\hline Firm Productivity & $\begin{array}{l}0.006 \\
(0.019)\end{array}$ & $\begin{array}{l}0.077 \\
(0.060)\end{array}$ \\
\hline Firm Performance Aspirations & $\begin{array}{l}0.632^{*} \\
(0.290)\end{array}$ & $\begin{array}{l}-0.040 \\
(0.575)\end{array}$ \\
\hline Repeated Internationalization & $\begin{array}{l}-0.631 * * * \\
(0.123)\end{array}$ & $\begin{array}{l}-0.811 \\
(0.511)\end{array}$ \\
\hline Age at First Internationalization & $\begin{array}{l}-0.174^{* * *} \\
(0.031)\end{array}$ & $\begin{array}{l}-0.261^{* *} \\
(0.087)\end{array}$ \\
\hline Institutional Distance & $\begin{array}{l}0.595 * * * \\
(0.089)\end{array}$ & $\begin{array}{l}1.617^{* * * *} \\
(0.189)\end{array}$ \\
\hline Related Industry Variety (local) & $\begin{array}{l}0.183^{*} \\
(0.072)\end{array}$ & $\begin{array}{l}0.090 \\
(0.173)\end{array}$ \\
\hline $\begin{array}{l}\text { Unrelated Industry Variety } \\
\text { (local) }\end{array}$ & $\begin{array}{l}0.116^{*} \\
(0.059)\end{array}$ & $\begin{array}{l}0.303^{*} \\
(0.144)\end{array}$ \\
\hline Intercept & $\begin{array}{l}-1.198 \\
(3.258)\end{array}$ & $\begin{array}{l}-6.944 \\
(8.408)\end{array}$ \\
\hline $\begin{array}{l}\text { International Experience } \\
\quad \text { (inflated variable) }\end{array}$ & $\begin{array}{l}-13.687^{* * *} \\
(1.627)\end{array}$ & $\begin{array}{l}-15.634 * * * \\
(1.095)\end{array}$ \\
\hline Intercept & $\begin{array}{l}-17.651^{* * *} \\
(1.050)\end{array}$ & $\begin{array}{l}-0.962 \\
(0.715)\end{array}$ \\
\hline lnalpha & $\begin{array}{l}-0.045 \\
(0.103)\end{array}$ & $\begin{array}{l}1.141^{* * *} \\
(0.219)\end{array}$ \\
\hline Cohort Dummies & Included & Included \\
\hline Industry Dummies & Included & Included \\
\hline Location Dummies & Included & Included \\
\hline Log-likelihood & -4182.25 & -1236.32 \\
\hline$N$ & 3005 & 3005 \\
\hline
\end{tabular}

$* p<0.05 ; * * p<0.01 ; * * * p<0.001$.

Notes: All models present the results of a zero-inflated negative binomial regression. In this model, we use international experience as an inflated variable, and we report the main model intercept, the first-stage intercept and the natural $\log$ of alpha (the dispersion parameter). Standard errors are clustered at the export-spell level (in parentheses).

Model 1 predicts the number of unique-to-the-geographic-market OR industry products.

Model 2 predicts the number of unique-to-the-geographic-market AND industry products.

up can benefit from unrelated industry variety and increase its exporting likelihood as well as persistence when its human resources are endowed with technological knowledge. Thus, to benefit from co-located businesses in unrelated industries to achieve internationalization, start-ups need technological "horsepower". Our results also show that having employees with international experience increases the positive relationship between related industry variety and a start-up's export persistence. Thus, the international experience of a start-up's human resources is important, especially for the firm to benefit from co-located businesses in related industries.

We conducted auxiliary analyses to provide evidence on the proposed mechanisms through which related and unrelated industry variety in a start-up's location improve the venture's internationalization. The documented mediation effects provide support to the proposed theoretical framework (that is, related industry variety $\rightarrow$ product innovation $\rightarrow$ internationalization of start-ups; unrelated industry
Table 6

Industry variety, employees' technological knowledge and international experience and start-up's persistence in exporting: The mediating role of product innovation.

\begin{tabular}{|c|c|c|}
\hline & Model 1 & Model 2 \\
\hline Industry Complexity & $\begin{array}{l}0.002 \\
(0.002)\end{array}$ & $\begin{array}{l}0.002 \\
(0.002)\end{array}$ \\
\hline Industry Export Orientation (ln) & $\begin{array}{l}0.224 \\
(0.213)\end{array}$ & $\begin{array}{l}0.242 \\
(0.211)\end{array}$ \\
\hline Cluster Location Quotient & $\begin{array}{l}0.015 \\
(0.009)\end{array}$ & $\begin{array}{l}0.014 \\
(0.009)\end{array}$ \\
\hline Firm Size $(\ln )$ & $\begin{array}{l}-0.221^{* * *} \\
(0.050)\end{array}$ & $\begin{array}{l}-0.239 * * * \\
(0.050)\end{array}$ \\
\hline Firm Age (ln) & $\begin{array}{l}0.615^{* * *} \\
(0.161)\end{array}$ & $\begin{array}{l}0.663^{* * *} \\
(0.161)\end{array}$ \\
\hline Firm Productivity & $\begin{array}{l}-0.017 \\
(0.015)\end{array}$ & $\begin{array}{c}-0.017 \\
(0.015)\end{array}$ \\
\hline Firm Performance Aspirations & $\begin{array}{l}-0.213 \\
(0.203)\end{array}$ & $\begin{array}{l}-0.228 \\
(0.206)\end{array}$ \\
\hline Repeated Internationalization & $\begin{array}{l}-0.619^{* * *} \\
(0.184)\end{array}$ & $\begin{array}{l}-0.634^{* * *} \\
(0.186)\end{array}$ \\
\hline Age at First Internationalization & $\begin{array}{l}-0.111^{*} \\
(0.051)\end{array}$ & $\begin{array}{l}-0.116^{*} \\
(0.052)\end{array}$ \\
\hline Institutional Distance & $\begin{array}{l}0.222^{* * * *} \\
(0.056)\end{array}$ & $\begin{array}{l}0.167^{* *} \\
(0.055)\end{array}$ \\
\hline Related Industry Variety (local) & $\begin{array}{l}-0.099 \\
(0.056)\end{array}$ & $\begin{array}{l}-0.134 * \\
(0.055)\end{array}$ \\
\hline Unrelated Industry Variety (local) & $\begin{array}{l}0.050 \\
(0.045)\end{array}$ & $\begin{array}{l}0.035 \\
(0.045)\end{array}$ \\
\hline Product Innovation & $\begin{array}{l}-0.335^{* * *} \\
(0.045)\end{array}$ & \\
\hline Breakthrough Product Innovation & & $\begin{array}{l}-0.157^{* *} \\
(0.058)\end{array}$ \\
\hline Cohort Dummies & Included & Included \\
\hline Industry Dummies & Included & Included \\
\hline Location Dummies & Included & Included \\
\hline Log-likelihood & -3611.01 & -3635.28 \\
\hline Chi2 & 1837.72 & 1209.96 \\
\hline$N$ & 3005 & 3005 \\
\hline Number of Internationalization Spells & 978 & 978 \\
\hline Number of Firms & 784 & 784 \\
\hline
\end{tabular}

$* p<0.05 ; * * p<0.01 ; * * * p<0.001$.

Note. This table presents the results of a Cox proportional hazard regression. The coefficients (and not the hazard ratios) are presented. Positive coefficients, implying an increase in the hazard of discontinuing exporting, mean a decrease in the duration of an export spell, i.e., a decrease in persistence, whereas negative coefficients, implying a decrease in the hazard of discontinuing exporting, mean an increase in the duration of an export spell, i.e., an increase in persistence with exporting. Standard errors are clustered at the export-spell level (in parentheses).

variety $\rightarrow$ breakthrough product innovation $\rightarrow$ internationalization of start-ups). Our findings contribute to three distinct streams of literature, as outlined below.

\subsection{Implications for international entrepreneurship literature}

Heeding prior calls by international business research indicating that "the context in which a firm operates still matters" (Buckley and Ghauri, 2004), our study shows that the relatedness of local industry variety in a start-up's location matters for its internationalization. Understanding the nature of local knowledge is important for start-ups because related and unrelated industry variety could both spur internationalization and impose costs on start-ups in terms of time and resources dedicated to assimilating such knowledge. Prior studies on international entrepreneurship have focused on the relevance of the home market location (Laursen et al., 2012; Zahra, 2005; Zander et al., 2015) and on the influence of local geographic clusters on new firms' internationalization outcomes (Fernhaber et al., 2008; Libaers and Meyer, 2011). In our study, we complement and extend this research stream by focusing on home locations characterized by local industry 
variety as important loci for assimilating and recombining knowledge across multiple areas and supporting the internationalization of startups.

\subsection{Implications for absorptive capacity in start-ups}

The learning and innovation benefits of variety have been discussed in a number of studies (Castaldi et al., 2015; Miles et al., 1993). It is argued that firms may benefit from exposure to multiple ideas and experiences; this exposure allows them to think creatively and develop novel combinations of knowledge (Levinthal and March 1993; Levitt and March 1988). Our study contributes to this research by showing that the net effect may partly depend on the characteristics of the learning environment (Barkema and Drogendijk, 2007). We find that related industry variety is more beneficial than unrelated industry variety for start-ups' exporting likelihood and persistence. However, the potential of unrelated industry variety can unravel when a start-up is endowed with human resources with technological knowledge.

\subsection{Implications for human resources in start-ups}

In our paper, we also propose that start-ups can reduce the costs and uncertainty involved in recombining knowledge spillovers from co-located firms in a variety of unrelated industries in their home location when they are endowed with human resources with technological knowledge and international experience. We find general support for these predictions but with some important distinctions. Our study shows that employees' technological knowledge enables start-ups to benefit from unrelated industry variety to increase both their exporting likelihood and their export persistence. These findings demonstrate that the opportunities to benefit from unrelated industry variety are ultimately conditional on a start-up's technological knowledge: start-ups that do not possess such knowledge are limited in the possibility of benefitting from unrelated industry variety for internationalization vis$\grave{a}$-vis those that possess it.

Our findings also show that the opportunities to benefit from related industry variety are not dependent upon the technological knowledge of a venture's human resources. It might, therefore, be that absorbing multiple knowledge that is related to a firm's ongoing activities is less dependent on the efforts of the firm's technical human resources. Cohen and Levinthal (1990) suggest that in extreme cases in which external knowledge is closely related to a firm's knowledge base, this absorption can be viewed as the byproduct of routine activities without necessarily requiring specific efforts by the firm's human resources.

We also find a positive interaction effect between international experience and related industry variety on export persistence; however, we do not find support for this interaction effect for unrelated industry variety. Employees with international experience may be able to leverage their international knowledge templates when recombining knowledge from related industry variety and creating novel products that are valuable for international markets. However, international experience might be less relevant when recombining knowledge from unrelated domains and creating breakthrough products for international markets. Such products might require substantial customer learning and the development of new international distribution channels and networks (Deszca et al., 1999), making prior templates related to international business less useful.

\subsection{Limitations and future directions}

Our study has some limitations that provide avenues for future research. First, the nature of our sample limits the generalizability of our findings to start-ups operating in industries that are distinctly different from the manufacturing industry and to start-ups located outside of Sweden. Additional testing will be required to assess the effect of local industry variety in non-manufacturing industry sectors and to determine whether these results hold for ventures located in other countries.

Second, similar to most internationalization studies, we are unable to assess the processes driving a firm's decision to internationalize. A complex set of resources and capabilities coupled with local knowledge coalesce to model the internationalization strategy of a start-up. Trade is an impeller for firms to gain access to knowledge (Grossman and Helpman, 1995), and exporting is a catalyst for firms to build a feedback loop between innovation and productivity (Aw et al., 2011). While the comprehensive data used in the study significantly increase the validity of the findings across manufacturing sectors in Sweden, this comprehensiveness is at the expense of a limited understanding of the firm-specific drivers of the internationalization decision. For example, one notable aspect could be the level of a start-up's motivation or willingness to internationalize (Zahra, 2005). The time-varying control of firm size and age (as well as human resources) allows us to proxy for unobservable firm-specific effects over time. However, future research could explore firm-specific drivers in more detail, including a start-up's willingness to internationalize. In making inferences, we also want to caution the reader that the Swedish economy is relatively small, and the effects observed here may not translate to the export dynamics among start-ups in larger or developing economies. Furthermore, we note that due to the smaller economy, the impetus to export is greater for Swedish firms (Coviello and Munro, 1995; Fan and Phan, 2007); in addition, cross-country unobservables in motivations to export may affect inferences in other contexts.

Third, because of data limitations, we were unable to consider the specific structure of the relationships among firms and the key actors in the home market location of start-ups or to observe "through which types of transfer mechanisms (trade linkages, labor mobility, networks, untraded linkages)" related and unrelated industry variety operate (Boschma and Iammarino, 2009: 306). Future research-through indepth case studies of specific locations or firms-could explore the transfer mechanisms and effects of knowledge spillovers and of more tangible resources from vertical networks, such as value chain partners (Cainelli and Iacobucci, 2012) or regional entrepreneurial ecosystems (Audretsch and Belitski, 2016). Finally, we study one country, whose local distribution of economic activities across sectors might not be representative of the local distribution of economic activities that characterize other countries. Thus, we cannot know whether in other countries there is a point - on the local industry variety continuum-at which a higher level of local industry variety starts having negative effects on internationalization. This limitation entails that the implications of our research need to be taken with caution and simultaneously calls for studies on the effects of local industry variety on startups' internationalization across countries with different patterns of technological specialization. Despite these limitations, our study shows that in Sweden, related industry variety has a positive effect on a startup's likelihood of and persistence in exporting, while the association between unrelated industry variety and exporting likelihood or persistence is conditional upon the technological knowledge of a venture's human resources.

\subsection{Policy implications}

Acknowledging that it remains a challenge to pinpoint the most effective tools that in practice would stimulate the mechanisms we have identified in our study, the broader policy implications of our study are threefold.

First, in countries with prominent policies promoting export, such as Sweden (cf. Sweden's Export Strategy, 2016), our findings demonstrate the value of the local industry structure-local industry variety-in explaining internationalization differences among start-ups. Traditional policies aimed at promoting the internationalization of start-ups typically entail instruments and export promotion programs that are directed at providing start-ups with foreign market information and 
guidance about how to internationalize (e.g., marketing assistance, sharing studies and research, mentoring from foreign offices) (Lederman et al., 2010). Our findings move a step forward and explain how the structural characteristics of a location can be a driver of startup internationalization. The effect of local industry variety on the internationalization of start-ups helps bring to the fore the importance of place-based policies-at the micro-geographic level, such as the municipality level-that may help design local industry structures by tailoring firm concessions based on the need for certain industries in the local economy and by favoring an ecology of related and complementary industries.

Second, the nature of human resources in a start-up is a consideration generally left to individual ventures. Although start-ups are important contributors to (net) job creation, there is a dearth of policy guidance on how policymakers can promote the recruitment and retention of certain employee types to improve internationalization outcomes. The implications of our findings in this regard are twofold. Although entrepreneurs may have the requisite human resources for internationalization, a start-up's formalisation and professionalization may require greater reflection of the necessary human resources among employees. As such, incentive programs and recruitment support for employees with technological knowledge and international experience may be useful. Furthermore, developing training programs to help employees invest or refine their technological knowledge and international experience may be useful.

Relatedly, while policymakers may not be able to change the industry structure that is already in place in a certain location, our findings provide preliminary evidence on the value of influencing human resources to hopefully yield desired internationalization outcomes. For example, in municipalities with high levels of unrelated industry variety, promoting the recruitment and retention of employees with technological knowledge may prime internationalization efforts. Conversely, in municipalities with high levels of related industry variety, policies that help promote the retention and recruitment of employees with internationalization experience may prime and sustain internationalization.

Third, our auxiliary analysis shows the value of innovation as a precursor to the internationalization of start-ups. Traditionally, policymakers have focused on innovation and internationalization policy separately in the sense that innovation policies are generally internally focused and internationalization policies are outwardly focused. Our findings suggest positive externalities from innovation to internationalization outcomes. As such, there may be avenues of cross-pollination between innovation and internationalization policies. Relevant policies could be, for example, entrepreneurship and innovation policies that are inspired by the Smart Specialization Strategy (3S) approach (McCann and Ortega-Argilés, 2015). This approach centers on start-ups' entrepreneurs and advocates for policies that support and reinforce their capacity to search for technological and industrial competences in their location (Boschma, 2014). Thus, innovation policies within the $3 \mathrm{~S}$ framework can be critical to spur the positive effects that we have observed in our study. In addition, our results on the positive effects of unrelated industry variety on breakthrough innovation and internationalization of start-ups with high levels of technological knowledge provide evidence in favor of the development of crossspecialization policies to create linkages between strong but unrelated industries in a region. As suggested by Janssen and Frenken (2019), this could be done by either targeting firms from cross-over industries or creating platform-like interfaces that allow firms to discover potential complementarities.

In summary, our study puts forward that a start-up's internationalization is a manifold of the nature of local industry variety, the nature of employee knowledge and experience relevant to related or unrelated industry variety, and the manifestation of these processes in the form of exported product innovation. Our findings somewhat help open a contingent black box that provides preliminary evidence of configurations for successful internationalization performance among start-ups: (i) related industry variety, international experience, and exported product innovation or (ii) unrelated industry variety, technological knowledge and breakthrough exported innovations. We hope that these findings spur future research on the local, firm, and innovation-related factors that coalesce to promote internationalization in start-ups.

\section{Declaration of Competing Interest}

We certify that we have NO affiliations with or involvement in any organization or entity with any financial interest (such as honoraria; educational grants; participation in speakers' bureaus; membership, employment, consultancies, stock ownership, or other equity interest; and expert testimony or patent-licensing arrangements), or non-financial interest (such as personal or professional relationships, affiliations, knowledge or beliefs) in the subject matter or materials discussed in this manuscript.

\section{Acknowledgement}

We are deeply grateful to our editor Alessandra Colombelli and two anonymous reviewers for their insightful feedback and guidance throughout the review process. We also wish to thank Silvio Esteve Pérez, Nicola Cortinovis and Charlotta Mellander for providing help and feedback on the methods. Finally, we are grateful to the Center for Entrepreneurship and Spatial Economics (CEnSE) and the Center for Family Entrepreneurship and Ownership (CeFEO) for supporting this study.

\section{References}

Aarstad, J., Kvitastein, O.A., Jakobsen, S.-.E., 2016. Related and unrelated variety as regional drivers of enterprise productivity and innovation: a multilevel study. Res Policy 45, 844-856.

Aarstad, J., Kvitastein, O.A., Jakobsen, S.E., 2019. Location decisions of enterprise R\&D investments as a function of related and unrelated regional industry structures: a multilevel study. Papers in Regional Science 98, 779-797.

Acs, Z.J., Terjesen, S., 2013. Born local: toward a theory of new venture's choice of internationalization. Small Business Economics 41, 521-535.

Alvarez, R., 2007. Explaining export success: firm characteristics and spillover effects. World Dev 35, 377-393.

Andersson, M., Larsson, J.P., Wernberg, J., 2019. The economic microgeography of diversity and specialization externalities-firm-level evidence from Swedish cities. Res Policy 48, 1385-1398.

Antonietti, R., Cainelli, G., 2011. The role of spatial agglomeration in a structural model of innovation, productivity and export: a firm-level analysis. Ann Reg Sci 46, $577-600$.

Antonietti, R., Gambarotto, F., 2018. The role of industry variety in the creation of in novative start-ups in Italy. Small Business Economics 1-13.

Ashby, W.R., Goldstein, J., 2011. Variety, constraint, and the law of requisite variety. Emergence: Complexity and Organization 13, 190.

Audretsch, D.B., Belitski, M., 2016. Entrepreneurial ecosystems in cities: establishing the framework conditions. Journal of Technology Transfer 1-22.

Autio, E., 2005. Creative tension: the significance of Ben Oviatt's and Patricia McDougall's article 'toward a theory of international new ventures' J Int Bus Stud 36, 9-19.

Autio, E., Sapienza, H.J., Almeida, J.G., 2000. Effects of age at entry, knowledge intensity, and imitability on international growth. Academy of Management Journal 43, 909-924.

Aw, B.Y., Roberts, M.J., Yi Xu, D., 2011. R\&D investment, exporting, and productivity dynamics. Am Econ Rev 101, 1312-1344.

Azar, G., Ciabuschi, F., 2017. Organizational innovation, technological innovation, and export performance: the effects of innovation radicalness and extensiveness. International Business Review 26, 324-336.

Barkema, H.G., Drogendijk, R., 2007. Internationalising in small, incremental or larger steps? J Int Bus Stud 38 1132-1132.

Baron, R.M., Kenny, D.A., 1986. The moderator-mediator variable distinction in social psychological research: conceptual, strategic, and statistical considerations. J Pers Soc Psychol 51, 1173.

Basile, R., 2001. Export behaviour of Italian manufacturing firms over the nineties: the role of innovation. Res Policy 30, 1185-1201.

Baum, J.A., Dahlin, K.B., 2007. Aspiration performance and railroads' patterns of learning from train wrecks and crashes. Organization Science 18, 368-385.

Baum, J.A., Li, S.X., Usher, J.M., 2000. Making the next move: how experiential and vicarious learning shape the locations of chains' acquisitions. Adm Sci Q 45, 
$766-801$.

Beise-Zee, R., Rammer, C., 2006. Local user-producer interaction in innovation and export performance of firms. Small Business Economics 27, 207-222.

Belderbos, R., Zou, J., 2007. On the growth of foreign affiliates: multinational plant networks, joint ventures, and flexibility. J Int Bus Stud 38, 1095-1112.

Bell, G.G., Zaheer, A., 2007. Geography, networks, and knowledge flow. Organization Science 18, 955-972.

Bell, J., 1995. The internationalization of small computer software firms: a further challenge to "stage" theories. Eur J Mark 29, 60-75.

Bernini, M., Du, J., Love, J.H., 2016. Explaining intermittent exporting: exit and conditional re-entry in export markets. J Int Bus Stud 47, 1058-1076.

Besedeš, T., Prusa, T.J., 2011. The role of extensive and intensive margins and export growth. J Dev Econ 96, 371-379.

Bingham, C.B., Davis, J.P., 2012. Learning sequences: their existence, effect, and evolution. Academy of Management Journal 55, 611-641.

Bishop, P., Gripaios, P., 2010. Spatial externalities, relatedness and sector employment growth in Great Britain. Reg Stud 44, 443-454.

Bloodgood, J.M., Sapienza, H.J., Almeida, J.G., 1996. The internationalization of new high-potential US ventures: antecedents and outcomes. Entrepreneurship Theory and Practice 20, 61-76.

Boschma, R., 2014. Constructing regional advantage and smart specialisation: comparison of two European policy concepts. Scienze Regionali.

Boschma, R., Iammarino, S., 2009. Related variety, trade linkages, and regional growth in Italy. Econ Geogr 85, 289-311.

Bruneel, J., Yli-Renko, H., Clarysse, B., 2010. Learning from experience and learning from others: how congenital and interorganizational learning substitute for experiential learning in young firm internationalization. Strategic Entrepreneurship Journal 4, 164-182.

Buckley, P.J., Ghauri, P.N., 2004. Globalisation, Economic Geography and the Strategy of Multinational Enterprises. J Int Bus Stud 35, 81-98.

Cadot, O., Carrère, C., Strauss-Kahn, V., 2011. Export diversification: what's behind the hump? Review of Economics and Statistics 93, 590-605.

Cainelli, G., Iacobucci, D., 2012. Agglomeration, related variety, and vertical integration. Econ Geogr 88, 255-277.

Cassiman, B., Golovko, E., 2011. Innovation and internationalization through exports. J Int Bus Stud 42, 56-75.

Castaldi, C., Frenken, K., Los, B., 2015. Related variety, unrelated variety and technological breakthroughs: an analysis of US state-level patenting. Reg Stud 49, 767-781.

Cezar, R., Escobar, O.R., 2015. Institutional distance and foreign direct investment. Review of World Economics 151, 713-733.

Chandra, Y., Styles, C., Wilkinson, I.F., 2012. An opportunity-based view of rapid internationalization. Journal of International Marketing 20, 74-102.

Chetty, S., Campbell-Hunt, C., 2004. A strategic approach to internationalization: a traditional versus a "born-global" approach. Journal of International Marketing 12, $57-81$.

Cohen, W.M., Levinthal, D., 1989. Innovation and learning: two faces of R\&D. Economic Journal 99, 569-596.

Cohen, W.M., Levinthal, D., 1990. Absorptive capacity: a new perspective on learning and innovation. Adm Sci Q 35, 128-152.

Colombelli, A., 2016. The impact of local knowledge bases on the creation of innovative start-ups in Italy. Small Business Economics 47, 383-396.

Colombelli, A., Quatraro, F., 2018. New firm formation and regional knowledge production modes: italian evidence. Res Policy 47, 139-157.

Coviello, N.E., Munro, H.J., 1995. Growing the entrepreneurial firm: networking for international market development. Eur J Mark 29, 49-61.

Crescenzi, R., Gagliardi, L., 2018. The innovative performance of firms in heterogeneous environments: the interplay between external knowledge and internal absorptive capacities. Res Policy 47, 782-795.

Danneels, E., 2002. The dynamics of product innovation and firm competences. Strategic Management Journal 23, 1095-1121.

De Clercq, D., Sapienza, H.J., Yavuz, R.I., Zhou, L., 2012. Learning and knowledge in early internationalization research: past accomplishments and future directions. Journal of Business Venturing 27, 143-165.

Dencker, J.C., Gruber, M., Shah, S.K., 2009. Pre-entry knowledge, learning, and the survival of new firms. Organization Science 20, 516-537.

Denicolai, S., Zucchella, A., Strange, R., 2014. Knowledge assets and firm international performance. International Business Review 23, 55-62.

Denrell, J., 2003. Vicarious learning, undersampling of failure, and the myths of management. Organization Science 14, 227-243.

Deszca, G., Munro, H., Noori, H., 1999. Developing breakthrough products: challenges and options for market assessment. Journal of Operations Management 17, 613-630.

Eckhardt, J.T., Shane, S.A., 2003. Opportunities and Entrepreneurship. J Manage 29, 333-349.

Esteve-Pérez, S., Mánez-Castillejo, J.A., Rochina-Barrachina, M.E., Sanchis-Llopis, J.A., 2007. A survival analysis of manufacturing firms in export markets.

Entrepreneurship, industrial location and economic growth. Cheltenham etc.: Elgar 313-332.

Fan, T., Phan, P., 2007. International new ventures: revisiting the influences behind the 'born-global'firm. J Int Bus Stud 38, 1113-1131.

Fernhaber, S.A., Gilbert, B.A., McDougall, P.P., 2008. International entrepreneurship and geographic location: an empirical examination of new venture internationalization. $J$ Int Bus Stud 39, 267-290.

Fernhaber, S.A., McDougall-Covin, P.P., Shepherd, D.A., 2009. International entrepreneurship: leveraging internal and external knowledge sources. Strategic Entrepreneurship Journal 3, 297-320.

Filatotchev, I., Liu, X., Buck, T., Wright, M., 2009. The export orientation and export performance of high-technology SMEs in emerging markets: the effects of knowledge transfer by returnee entrepreneurs. J Int Bus Stud 40, 1005-1021.

Filipescu, D.A., Prashantham, S., Rialp, A., Rialp, J., 2013. Technological innovation and exports: unpacking their reciprocal causality. Journal of International Marketing 21, 23-38.

Fleming, L., 2001. Recombinant uncertainty in technological search. Manage Sci 47, $117-132$.

Fletcher, M., Harris, S., 2012. Knowledge acquisition for the internationalization of the smaller firm: content and sources. International Business Review 21, 631-647.

Frenken, K., Van Oort, F., Verburg, T., 2007. Related variety, unrelated variety and regional economic growth. Reg Stud 41, 685-697.

Ganotakis, P., Love, J.H., 2010. R\&D, product innovation, and exporting: evidence from UK new technology based firms. Oxf Econ Pap 63, 279-306.

Ganotakis, P., Love, J.H., 2012. Export propensity, export intensity and firm performance: the role of the entrepreneurial founding team. J Int Bus Stud 43, 693-718.

Ghemawat, P., 2007. Redefining global strategy: crossing borders in a world where differences still matter. Harvard Business Press.

Gilsing, V., Nooteboom, B., Vanhaverbeke, W., Duysters, G., van den Oord, A., 2008. Network embeddedness and the exploration of novel technologies: technological distance, betweenness centrality and density. Res Policy 37, 1717-1731.

Gimmon, E., Levie, J., 2010. Founder's human capital, external investment, and the survival of new high-technology ventures. Res Policy 39, 1214-1226.

Grabher, G., 1993. In: Grabher, G. (Ed.), The embedded firm: On the socio-economics of industrial networks. Routledge, London, pp. 255-277 (Ed.).

Grant, R.M., 1996. Toward a knowledge-based theory of the firm. Strategic Management Journal 17, 109-122.

Grossman, G.M., Helpman, E., 1995. Technology and trade (Eds.) In: Gopinath, G., Helpman, E., Rogoff, K. (Eds.), Handbook of International Economics, pp. 1279-1337.

Gruber, M., MacMillan, I.C., Thompson, J.D., 2008. Look before you leap: market opportunity identification in emerging technology firms. Manage Sci 54, 1652-1665.

Gruber, M., MacMillan, I.C., Thompson, J.D., 2013. Escaping the prior knowledge cor ridor: what shapes the number and variety of market opportunities identified before market entry of technology start-ups? Organization Science 24, 280-300.

Hargadon, A., Sutton, R.I., 1997. Technology Brokering and Innovation in a Product Development Firm. Adm Sci Q 42, 716-749.

Heckman, J.J., 1979. Sample selection bias as a specification error. Econometrica 47 $153-161$.

Herman, P., Horowitz, J., Torsekar, M., 2018. Competitive Conditions Affecting US Exports of Medical Technology to Key Emerging Markets. ECONOMICS WORKING PAPER SERIES. U.S. INTERNATIONAL TRADE COMMISSION.

Huyghebaert, N., Van de Gucht, L.M., 2004. Incumbent strategic behavior in financial markets and the exit of entrepreneurial start-ups. Strategic Management Journal 25 $669-688$.

Iammarino, S., McCann, P., 2013. Multinationals and economic geography: location, technology and innovation. Edward Elgar Publishing.

Jacobs, J., 1970. The economy of cities.

Janssen, M.J., Frenken, K., 2019. Cross-specialisation policy: rationales and options for linking unrelated industries. Cambridge Journal of Regions, Economy and Society 12, 195-212.

Katila, R., Ahuja, G., 2002. Something old, something new: a longitudinal study of search behavior and new product introduction. Academy of Management Journal 45 1183-1194.

Keupp, M.M., Gassmann, O., 2009. The past and the future of international entrepreneurship: a review and suggestions for developing the field. J Manage 35, 600-633.

Knight, G.A., Cavusgil, S.T., 2004. Innovation, organizational capabilities, and the born global firm. J Int Bus Stud 35, 124-141.

Knight, G.A., Liesch, P.W., 2002. Information internalisation in internationalising the firm. J Bus Res 55, 981-995.

Kotha, R., Zheng, Y., George, G., 2011. Entry into new niches: the effects of firm age and the expansion of technological capabilities on innovative output and impact. Strategic Management Journal 32, 1011-1024.

Kumar, M.V.S., 2009. The relationship between product and international diversification: the effects of short-run constraints and endogeneity. Strategic Management Journal $30,99-116$.

Kyläheiko, K., Jantunen, A., Puumalainen, K., Saarenketo, S., Tuppura, A., 2011. Innovation and internationalization as growth strategies: the role of technological capabilities and appropriability. International Business Review 20, 508-520.

Lamin, A., Livanis, G., 2013. Agglomeration, catch-up and the liability of foreignness in emerging economies. J Int Bus Stud 44, 579-606.

Lane, P.J., Lubatkin, M., 1998. Relative absorptive capacity and interorganizational learning. Strategic Management Journal 19, 461-477.

Lane, P.J., Salk, J.E., Lyles, M.A., 2001. Absorptive capacity, learning, and performance in international joint ventures. Strategic Management Journal 22, 1139-1161.

Laursen, K., Masciarelli, F., Prencipe, A., 2012. Trapped or spurred by the home region\& quest; The effects of potential social capital on involvement in foreign markets for goods and technology. J Int Bus Stud 43, 783-807.

Lederman, D., Olarreaga, M., Payton, L., 2010. Export promotion agencies: do they work? J Dev Econ 91, 257-265.

Levinthal, D.A., March, J.G., 1993. The myopia of learning. Strategic Management Journal 14, 95-112.

Levitt, B., March, J.G., 1988. Organizational learning. Annu Rev Sociol 14, 319-340.

Libaers, D., Meyer, M., 2011. Highly innovative small technology firms, industrial clusters and firm internationalization. Res Policy 40, 1426-1437.

Lööf, H., Nabavi, P., 2014. Survival, productivity and growth of new ventures across 
locations. Small Business Economics 43, 477-491.

Love, J.H., Máñez, J.A., 2019. Persistence in exporting: cumulative and punctuated learning effects. International Business Review 28, 74-89.

Lu, J., Liu, X., Wright, M., Filatotchev, I., 2014. International experience and FDI location choices of Chinese firms: the moderating effects of home country government support and host country institutions. J Int Bus Stud 45, 428-449.

Madsen, T.K., Servais, P., 1997. The internationalization of born globals: an evolutionary process? International Business Review 6, 561-583.

Mainela, T., Puhakka, V., Servais, P., 2014. The concept of international opportunity in international entrepreneurship: a review and a research agenda. International Journal of Management Reviews 16, 105-129.

Malerba, F., 2002. Sectoral systems of innovation and production. Res Policy 31 247-264.

McCann, B.T., Folta, T.B., 2008. Location matters: where we have been and where we might go in agglomeration research. J Manage 34, 532-565.

McCann, P., Ortega-Argilés, R., 2015. Smart specialization, regional growth and applications to European Union cohesion policy. Reg Stud 49, 1291-1302.

McCann, P., Simonen, J., 2005. Innovation, knowledge spillovers and local labour markets. Papers in Regional Science 84, 465-485.

Miguelez, E., Moreno, R., 2018. Relatedness, external linkages and regional innovation in Europe. Reg Stud 52, 688-701.

Miles, G., Snow, C.C., Sharfman, M.P., 1993. Industry variety and performance. Strategic Management Journal 14, 163-177.

Minbaeva, D., Pedersen, T., Bjorkman, I., Fey, C.F., Park, H.J., 2003. MNC knowledge transfer, subsidiary absorptive capacity, and HRM. J Int Bus Stud 34, 586-599.

Mudambi, R., Zahra, S.A., 2007. The survival of international new ventures. J Int Bus Stud $38,333-352$.

Murmann, J.P., Ozdemir, S.Z., Sardana, D., 2015. The role of home country demand in the internationalization of new ventures. Res Policy 44, 1207-1225.

Namiki, N., 1988. Export strategy for small business. Journal of Small Business Management 26, 32-37.

Nassimbeni, G., 2001. Technology, innovation capacity, and the export attitude of small manufacturing firms: a logit/tobit model. Res Policy 30, 245-262.

Nonaka, I., Teece, D.J., 2001. Managing industrial knowledge: creation, transfer and utilization. Sage.

Nooteboom, B., 2000. Learning and innovation in organizations and economies. Oxford University Press.

Nooteboom, B., Van Haverbeke, W., Duysters, G., Gilsing, V., van den Oord, A., 2007. Optimal cognitive distance and absorptive capacity. Res Policy 36, 1016-1034.

Olausson, D., Berggren, C., 2010. Managing uncertain, complex product development in high-tech firms: in search of controlled flexibility. R\&D Management 40, 383-399.

Paci, R., Usai, S., 1999. Externalities, knowledge spillovers and the spatial distribution of innovation. GeoJournal 49, 381-390.

Patel, P., Vega, M., 1999. Patterns of internationalisation of corporate technology: location vs. home country advantages. Res Policy 28, 145-155.

Penrose, E., 1959. The Theory of the Growth of the Firm. Oxford University Press, Oxford 3rd ed. ed.

Petersen, B., Pedersen, T., Lyles, M.A., 2008. Closing knowledge gaps in foreign markets. J Int Bus Stud 39, 1097-1113.

Phene, A., Fladmoe-Lindquist, K., Marsh, L., 2006. Breakthrough innovations in the US biotechnology industry: the effects of technological space and geographic origin. Strategic Management Journal 27, 369-388.

Posen, H.E., Chen, J.S., 2013. An Advantage of Newness: vicarious Learning Despite Limited Absorptive Capacity. Organization Science 24, 1701-1716.

Preacher, K.J., Rucker, D.D., Hayes, A.F., 2007. Addressing moderated mediation hypotheses: theory, methods, and prescriptions. Multivariate Behav Res 42, 185-227.

Qian, G., Khoury, T.A., Peng, M.W., Qian, Z., 2010. The performance implications of intra- and inter-regional geographic diversification. Strategic Management Journal 31, 1018-1030.

Rodríguez-Ruiz, F., Almodóvar, P., Nguyen, Q.T., 2019. Intellectual structure of international new venture research: a bibliometric analysis and suggestions for a future research agenda. Multinational Business Review.

Schilling, M.A., Vidal, P., Ployhart, R.E., Marangoni, A., 2003. Learning by doing some thing else: variation, relatedness, and the learning curve. Manage Sci 49, 39-56.
Schwens, C., Zapkau, F.B., Bierwerth, M., Isidor, R., Knight, G., Kabst, R., 2018. International entrepreneurship: a meta-analysis on the internationalization and performance relationship. Entrepreneurship Theory and Practice 42, 734-768.

Shane, S., 2000. Prior Knowledge and the Discovery of Entrepreneurial Opportunities. Organization Science 11, 448-469.

Shenkar, O., Li, J., 1999. Knowledge search in international cooperative ventures. Organization Science 10, 134-143.

Shepherd, D.A., DeTienne, D.R., 2005. Prior knowledge, potential financial reward, and opportunity identification. Entrepreneurship Theory and Practice 29, 91-112.

Sterlacchini, A., 1999. Do innovative activities matter to small firms in non-R\&D-intensive industries? An application to export performance. Res Policy 28, 819-832.

Stoian, M.-.C., Dimitratos, P., Plakoyiannaki, E., 2018. SME internationalization beyond exporting: a knowledge-based perspective across managers and advisers. Journal of World Business 53, 768-779.

Strategy, S.s.E., 2016. Government offices of Sweden.

Stucki, T., 2016. How the founders' general and specific human capital drives export activities of start-ups. Res Policy 45, 1014-1030.

Sui, S., Baum, M., 2014. Internationalization strategy, firm resources and the survival of SMEs in the export market. J Int Bus Stud 45, 821-841.

Tavassoli, S., Carbonara, N., 2014. The role of knowledge variety and intensity for regional innovation. Small Business Economics 43, 493-509.

Teixeira, A.A.C., Tavares-Lehmann, A.T., 2014. Human capital intensity in technologybased firms located in Portugal: does foreign ownership matter? Res Policy 43, 737-748.

Trajtenberg, M., 2001. Innovation in Israel 1968-1997: a comparative analysis using patent data. Res Policy 30, 363-389.

Vahlne, J.-.E., Bhatti, W.A., 2019. Relationship Development: a Micro-Foundation for the Internationalization Process of the Multinational Business Enterprise. Management International Review 59, 203-228.

Vernon, R., 1966. International trade and international investment in the product cycle. Quarterly journal of economics 80, 190-207.

Welch, C.L., Welch, L.S., 2009. Re-internationalisation: exploration and conceptualisation. International Business Review 18, 567-577.

Wolff, J.A., Pett, T.L., 2000. Internationalization of small firms: an examination of expor competitive patterns, firm size, and export performance. Journal of Small Business Management 38, 34.

Wu, Z., Salomon, R., 2016. Does imitation reduce the liability of foreignness? L inking distance, isomorphism, and performance. Strategic Management Journal 37, 2441-2462.

Yang, H., Phelps, C., Steensma, H.K., 2010. Learning from what others have learned from you: the effects of knowledge spillovers on originating firms. Academy of Management Journal 53, 371-389.

Yeoh, P.-.L., 2004. International learning: antecedents and performance implications among newly internationalizing companies in an exporting context. International Marketing Review 21, 511-535.

Yu, J., Gilbert, B.A., Oviatt, B.M., 2011. Effects of alliances, time, and network cohesion on the initiation of foreign sales by new ventures. Strategic Management Journal 32, 424-446.

Zahra, S., George, G., 2002. Absorptive capacity: a review, reconceptualization, and extension. Academy of Management Review 27, 185-203.

Zahra, S., Ireland, D.R., Hitt, M.A., 2000. International expansion by new venture firms: international diversity, mode of market entry, technological learning, and performance. Academy of Management Journal 43, 925-950.

Zahra, S.A., 2005. A theory of international new ventures: a decade of research. J Int Bus Stud 36, 20-28.

Zahra, S.A., Matherne, B.P., Carleton, J.M., 2003. Technological resource leveraging and the internationalisation of new ventures. Journal of International Entrepreneurship 1, 163-186.

Zander, I., McDougall-Covin, P., Rose, E.L., 2015. Born globals and international business: evolution of a field of research. J Int Bus Stud 46, 27-35.

Zelner, B.A., 2009. Using simulation to interpret results from logit, probit, and other nonlinear models. Strategic Management Journal 30, 1335-1348.

Zollo, M., 2009. Superstitious learning with rare strategic decisions: theory and evidence from corporate acquisitions. Organization Science 20, 894-908. 